\title{
Moving Pictures in Motion: Methods of Geographical Analysis and Visualisation in Comparative Research on Local Film Exhibition Using a Case Study of Brno and Ghent in 1952
}

\begin{abstract}
In recent years, spatial digital tools have become an important part of New Cinema History research. However, the use of spatial visualisation methods remains inconsistent and the ground norms have yet to be established, especially in a comparative approach. In this paper, we explore the possibilities of working with spatial visualisation: what are the benefits of its use and what new perspectives on a given problem can this approach reveal? Drawing on a quantitative analysis of cinema programmes, we incorporate geospatial as well as temporal aspects of film trajectories. In doing so, we explore to what extent the communication between cinemas and their strategies of programming can be explained through the geospatial perspective. By visualising the film circulation within two mid-sized cities (Ghent in Belgium and Brno in the Czech Republic) in 1952, the method reveals patterns in film trajectories and relationships between the cinemas. These findings show the potential for the incorporation of geospatial visualisation in a comparative research design.
\end{abstract}

\section{Keywords}

comparative research; digital tools; spatial analysis; mapping; cinema history; Brno; Ghent; 1950s

For the past two decades, a growing international community of researchers in the humanities has been drawn to the examination of history from a geographical perspective. ${ }^{1}$ Cinema historians have been exploring the possibilities of mapping, as well as other digital tools for analysing film culture and audiences, under the label of New Cinema History. ${ }^{2}$ Along with the digital tools, a comparative approach to the historical research has gained popularity, in addition to case studies updating methodological designs in comparative cinema studies. This paper aims to enrich this body of work, focusing mainly on the challenges of these new methods and tools for comparative research. 


\section{Digital tools in historical data visualisation}

As Robert C. Allen and Douglas Gomery pointed out more than three decades ago, film as a product is not the only, nor the most important source. ${ }^{3}$ The perspective of New Cinema History broadens the scope of research from a film as a text to cinema in its wider social and cultural context, which also places higher demands on the variety of source materials. To conduct research on cinema history, a much broader and more diverse set of resources need to be examined. ${ }^{4}$ From archival materials on films and cinemas and their institutional background, through to the demographic, architectural and cultural context to cinema programmes, the data are being collected and stored in databases serving not only as storage but also as a tool for managing, presenting and spreading the knowledge among a broader public. ${ }^{5}$ Furthermore, scholars are going beyond traditional film studies and looking for suitable methods of research and analysis in the fields of sociology, ethnography, geography, history, computational sciences etc. ${ }^{6}$ The use of digital tools in research on cinema history has enabled a more precise spatial, temporal and network visualisation of the historical data. Visualisation is a method that improves the understanding of the history in its spatial and temporal dimension as well as in the network of relationships between actors or objects. Based on this visualisation, the next step can be taken - the analysis of these spatial, temporal and network representations of history. Their efficiency as well as the associated challenges of working with them have been tested in numerous studies focusing on collecting and analysing big data, creating spatial visualisations and working with the temporal aspect of data. ${ }^{7}$

In many fields of study, such as social sciences, history or literature, sound methodologies of adapting digital tools to the specificities of the research have already been developed. The tools that were in many cases originally intended to perform other tasks, have, over time and with intensive use, been naturalised in the field. ${ }^{8}$ As the application of digital tools is not yet rooted that well in cinema studies, there are numerous instances where researchers have tried to adjust various tools, used in other academic fields, exploring their possibilities but also their limitations. One of the digital tools that considerably widens the opportunities of cinema history research is the use of databases. This tool has been created to store large sets of raw data and is being extensively used in the social sciences thanks to its ability to keep the data structured. The clear structure of a database ensures efficient quantitative data analysis and comparison. ${ }^{9}$ The awareness of the types of digital tools and methods of use has increased in the past few decades, mainly thanks to the research activities within 
the New Cinema History field. Several academic teams in different parts of the world have developed research projects raising awareness not only about the given local film culture and cinema history, but also about the tools and techniques for their visualisation and consecutive analysis.

One of the pioneering big-data projects is Cinema Context, a database of contextual infrastructure for the history of film culture in the Netherlands that provides basic information about the film exhibition and distribution practices in the country. ${ }^{10}$ Although this project functions primarily as a storage of data, the structured format of the database allows researchers to take it to the next level - visualisation and analysis. Many of the projects within cinema history with similar databases on the background have reached for the spatial, temporal and/or network analysis, as for example the Kinomatics Project, ${ }^{11}$ Going to the Show: Mapping Moviegoing in North Carolina $^{12}$ or the Mapping Movies ${ }^{13}$ project. While in the United States, Jeffrey Klenotic in Mapping Movies and Robert C. Allen in Going to the Show primarily work with the geographical visualisation of cinema history data and contextual social-historical data on a map or series of maps, an Australian team of Deb Verhoeven, Colin Arrowsmith and Alwyn Davidson moves the visual representation of data in the Kinomatics Project from the geographical space to more abstract but, from a certain perspective, richer visualisations of the specific cinema history data. By deviating from the map visualisation, they initiate a debate on the effective visualisation of multivariate spatial and temporal data. ${ }^{14}$ In their work, they use a varied set of digital tools for the visualisation of the space, time and networks within which the researched objects (cinema venues) existed and also within which the exhibition and distribution practices were applied. They propose and test a set of digital tools from the more traditional, for example choropleth maps and cartograms, ${ }^{15}$ to tools adopted from other scientific disciplines (Markov chains ${ }^{16}$, circular visualisations with $\left.\operatorname{Cir} \cos ^{17}\right)$, to a tool developed specifically for the visualisation of the multivariate spatial and temporal data on cinema history, the Petal diagrams. ${ }^{18}$ Similarly, the Graphomap, a specific graphical visualisation somewhere between a map and a graph developed by the team led by Sébastian Caquard, breaks down the unity of geographical space in order to create a more precise and more suitable visualisation combining sociodemographic data with cinema history data. ${ }^{19}$ Inspired by these projects, this case study oscillates between the importance of the geographical space for the local history of cinemas; the precision in depicting the temporal aspect of historical data; and the aim of researching the cinema venues and film exhibition practices not as independently existing processes, but as part of a complex network of relationships. Instead of 
attempting to include all three factors into one graphic depiction, we decided to focus on each aspect separately and look for overlaps that can be combined in a visualisation.

\section{Visualisation and comparative method}

When choosing a comparative perspective, interdisciplinary and international collaboration becomes compelling, sometimes even inevitable. ${ }^{20}$ An explicit comparative approach, together with the application of digital tools for visualisation, is still a new and challenging area for (new) cinema studies. ${ }^{21}$ The body of work comparing cinema histories grows every year, whereas digital visualisation or analyses are yet to be broadly applied. There are numerous studies implicitly or explicitly comparing different aspects of film culture and audiences, however, the prevailing research method involves more traditional historical analyses of archival materials concerning the institutional background of distribution and exhibition practices. ${ }^{22}$ Rare examples, however, show that digital tools might be very helpful in comparative cinema history research. In his book Wechselnde Vorlieben: Über Die Filmpräferenzen Der Europäer 1896-1939, Joseph Garncarz applies a quantitative approach to attendance rates in order to compare audiences' film preferences in different European states. ${ }^{23}$ Meanwhile, Economist John Sedgwick has developed a digital tool specifically for film business research, a formula called POPSTAT, for the precise quantitative analysis of the commercial status of films in a given city, which can work as good at the local level as in international comparison. ${ }^{24} \mathrm{~A}$ digital visual representation of comparative cinema history is also considerably rare. We find it mostly in the form of a more general overview or comparison on the level of one or more countries. Eliza Ravazzoli, for example, focuses in her case study on the identification of the nodes of film production in Italy, their spatial localisation and comparison. ${ }^{25}$ This research is an example of a thorough use of spatial visualisation and analysis of the film industry. Another example also maps fairly recent data on international exchanges of digital cinema in order to understand cultural reciprocity. Arrowsmith, Verhoeven, Bronwyn Coate and Stuart Palmer use network visualisation for the analysis of the dynamics of shared cultural exchange worldwide. ${ }^{26}$ Within this context of research on the visual representation and analysis of the spatial and temporal dimension of cinema data, as well as on the network analysis of relationships within film distribution, exhibition and cinema history, we endeavour in the following case study to try out a set of digital tools and methods that can enhance and broaden the comparative approach to cinema history. 


\section{Case study}

This case study is part of a cinema history project researching methods for the analysis and comparison of data from historical sources stored in relational databases and the use of digital tools in the analysis of the spatial and temporal aspects of these data. By comparing two distinct historical and geospatial contexts, Belgium and Czechoslovakia in the early 1950s, we propose, test and evaluate a set of methods for data analysis and visualisation, with a focus on geographical mapping. We primarily focus on identifying the opportunities and challenges of their application in comparative historical research. As Jerry Brotton reminds us, maps 'offer arguments and propositions; they define, recreate, shape and mediate' ${ }^{27}$ Rather than provide straightforward answers, maps leave their interpretation to the reader. Through this case study, we suggest and evaluate research methods and make a plea for a broader interpretation of results, our findings constituting a rich source of information for future research and discussions on the comparison of local cinema histories. Therefore, we mainly focus on the contribution and efficiency of the proposed analyses and visualisations for the comparative research of local cinema histories, leaving the detailed interpretation of results for future case studies.

The case study consists of four methodological strands. The first shows the benefits of the spatial visualisation of historical data. We position the cinemas within the urban structures and compare the resulting spatial settings based on the distance (from each other, from the city centre) or the arrangement in space. Thanks to the visualisation, we are also able to assess the spread of programming data availability for each cinema more effectively. In the second strand, we quantitatively analyse the film trajectories to construct a hierarchisation of cinemas and look for similarities in the cinema networks across the Iron Curtain, as opposed to the clear-cut run-zoneclearance distribution model developed in the classical Hollywood studio system. ${ }^{28}$ We reconstruct a hierarchy of cinemas that reflects the local film circulation in each city. We visualise these categories in maps to assess and compare their distribution in the geospatial settings of the two cities. This is an example of the quantitative analysis of cinema programmes and how an additional, non-spatial feature of cinemas (the categories) can be displayed on a map. Network analysis is the focus of the third strand. This type of analysis reveals relations between objects based on a given attribute. In our case, we analyse similarities in the cinemas' film offer and categorise their mutual relationships based on the number of shared films. The more films two cinemas have in common, the stronger the 
connection between them appears. The visualisation of this network does not reflect the geospatial layout. The arrangement of points, however, is not random. Their position within the network and their mutual distance give priority to displaying the common feature rather than geographical space. Finally, in the fourth strand, we examine the possibilities of analysis and visualisation provided by the temporal aspect of local film exhibition. We analyse the circulation of films in the cities and examine the challenges and benefits of recording the temporal pattern in a graphic visualisation. Rather than using a visualisation in a map, we apply a graphic representation of the timelines to ensure the comparison of temporal patterns is clear and easy.

\section{Selection of the cities}

We chose three cities similar in size and located in two countries. Inspired by the industry studies approach, we compared their cinema networks and exhibition scenes against the background of their national film industries. Brno in former Czechoslovakia, and Antwerp and Ghent in Belgium are three medium-sized cities with cinematographic networks and, at the beginning of the 1950s, there were approximately 35-36 cinemas in Brno and Ghent, and 54 in Antwerp. This range may seem imbalanced; however, it not the total amount of cinemas that are analysed here, but the number of cinemas for which the source data are available. In all three cities, there is a group of cinemas we had to exclude due to the unavailability or deficiency of the source data.

The choice of cities is rooted in the primary goal of the broader research project to explore the potential of comparative methods for New Cinema History. It also brings a unique opportunity to compare cinema networks and exhibition strategies between two considerably different systems of the film industry. In the 1950s, Czechoslovakia was already a part of the Eastern Bloc, the group of communist states under the hegemony of the Soviet Union. The Czechoslovak film industry was nationalised, and the state had an exclusive right to manage all departments of the film industry: production, distribution and exhibition. ${ }^{29}$ However, the national film monopoly had to cope with many problems which appeared after World War II. Due to the continual suppression of the import of films from Western Europe and the United States and an insufficient supply of films from the Soviet Union which were supposed to substitute for Western productions, the Czechoslovak distribution suffered from a shortage of films. The state regulations of film distribution and exhibition led to attempts to prioritise those Soviet titles which were of higher value for the communist regime. 
To secure high attendance numbers, the films were screened within so-called 'circular distribution', which ensured screenings in selected cinemas all over the city. This practice, however, lasted only for less than four years, from 1949 until mid-1953.30 Interestingly, despite the strict regulation of all levels of the film industry, it seems that the cinema venues, although nationalised, did not fall under any official hierarchisation. It is true they were divided into three groups to scale the ticket prices, however, this categorisation was based on the size of the city and the technological equipment of the cinema. These categories, unlike the strict cinema hierarchy established during the Protectorate by the German administration, did not officially decide the films' trajectories within a city. ${ }^{31}$

The Czechoslovak state film monopoly bears a resemblance to the studio monopoly of the five largest production companies from Hollywood's pre-war golden age, with vertical integration ensuring that films were distributed to all of the cinema venues within their own cinema chains. The high level of efficiency of the distribution and exhibition practices were supported by the run-zoneclearance system; a system of exhibition segregating the film bookings by runs within a territory and for a fixed period of time. The film would firstly go to the first-run cinemas, after which a clearance would follow, an interval of a seven to thirty days break before the screening in the second run. The same practice would be applied between the second and third run and so on. Throughout the classic studio era, this run-zone-clearance system served to maximise the revenues of the biggest Hollywood studios which also owned chains of cinemas, and it was only modified at the end of the 1940s within the government's antitrust campaign. ${ }^{32}$ However, the Belgian liberal film market, free of strict official censorship and minimal national production, attracted foreign productions, especially Hollywood and French films, that engulfed the Belgian distribution. ${ }^{33}$ After the war, the film market was exposed to Hollywood production and their practices of block-booking and blind-binding. ${ }^{34}$ The liberal market and cinema network without monopoly standing against the Czechoslovak national monopoly creates an opportunity to compare the film exhibition practices and the nature of film circulation and films' trajectories at a local level across the Iron Curtain.

\section{Data and methods}

In this case study, we use three datasets, each concerning one of the cities in focus. The datasets come from different sources but store similar content in a very similar format. The Antwerp data were collected within the projects The Enlighted City and Antwerpen Kinemastad, ${ }^{35}$ the data on Ghent were 
compiled first within the projects The Enlighted City and Gent Kinemastad and later the European Cinema Audiences project currently in development ${ }^{36}$ and, finally, the data on Brno came from both the already mentioned European Cinema Audiences project and the Cinematic Brno project. ${ }^{37}$ All three of these projects use a relational database on the background of the user interface: The information on cinema venues, their geographical localisation, opening and closing days, number of seats, managers and, most importantly, programmes. The cinema programmes consist of the dates of screening, title of film and additional notes. These data were collected from the regional or local newspapers and, in the case of Antwerp, from the business archives of the Rex cinema group of Georges Heylen. The titles here were usually listed in the local language, therefore additional identification of the titles was required. The original title, country and year of production, and director were added. The majority of films were identified via the International Movie Database (IMDb). ${ }^{38}$ These films also received a unique identifier from the IMDb database that made it possible to search for the film in the IMDb database. The data are stored and arranged in a similar structure in all three databases. This allowed us to apply the same methods to each without any further structural adjustments.

The results of the analysis directly depend on data availability and integrity. The data in this study were assembled from archival sources, such as year books, annual reports of film companies and exhibitors' associations, and local newspapers. In the case of Brno, local newspapers were the only source of cinema programmes. Although this source provided us with an almost complete overview of the programming structure of most of the cinemas located in the city centre and the surrounding neighbourhoods, programmes of cinemas located in the districts further away from the centre were published only scarcely or not at all. In the case of Antwerp, the limitations stem from the general focus of the project being aimed only at a specified set of cinemas in the central part of the city. Programmes of these cinemas were collected, leaving aside the analyses of cinemas' hierarchisation or film trajectories. Therefore, some of the following analyses focus only on the comparison of Ghent and Brno.

The methods we propose focus on an effective depiction of the spatial and temporal aspect of the historical data, together with their positioning within a wider network of relations. ${ }^{39}$ Instead of trying to incorporate all these aspects into one visualisation, as in the aforementioned Petal Diagrams, we decided to divide the space, time and relationships into three different visualisations. We used tools that have already been introduced in cinema studies, though not in a comparative 
approach. The spatial visualisation and analysis keep the traditional form of a set of maps depicting the geographical space and the cinemas localised within it. For that we used ArcGIS software, one of the digital geographic information systems for working with maps and geographic information. ${ }^{40}$ The digital tool for network analysis which helped us to create visualisations of the relations between the cinemas, is Gephi, an open source piece of software for graph and network analysis. We applied the Force Atlas 2 algorithm that is scaled for small to medium size graphs and is adapted to the qualitative interpretation of graphs. In this layout, the nodes repulse like charged particles, while edges attract their nodes, like springs, based on the strength of their connection, which is defined by the number of connections between each two nodes. In the final network, the nodes with the strongest connections are close to each other, whereas the ones not strongly related to any of the other nodes lie on the outskirts of the clusters. ${ }^{41}$ For the temporal analysis of circulation of the film within the cities, we only used the basic table design, whereby we depict the exhibition life of the selected films. This visualisation secures all the aspects of the data required for comparison - the succession of cinemas in the film trajectory, the length of screenings in each of them, the length of the breaks between the screenings, and, importantly, the divisions from the linear trajectory, as for example the simultaneous screenings in several cinemas or the returning of the film to the same cinema after some time.

\section{Spatial localisation}

In the first step, we created a set of three maps, each representing one city. The primary goal was to visualise the general structure of the cinema networks in geographical space to better grasp the local exhibition scenes. In this part, we examine the possibilities of geospatial visualisation; we ask to what extent it can improve the historical research and if it is able to reveal features of the source materials hitherto hidden or unnoticed. ${ }^{42}$ As Jerry Brotton notes, 'every map shows one thing, but therefore not another, and represents the world in one way, and as a consequence not in another'. ${ }^{43}$ When creating maps, the researcher needs to be ready to undertake a certain amount of generalisation, simplifying some of the map attributes, in order to maintain the efficiency of the visualisation and the readability of the final map. ${ }^{44}$ As the name suggests, the thematic maps serve to display a certain theme, to describe patterns, to illustrate a story. ${ }^{45}$ The map cannot visualise every aspect of the geographical space; the amount of information that can be displayed on a map is limited and so is the nature of the information. The main pre-requisite of an object to be visualised on a map is its spatial aspect. In 
cartography, only geographically well-defined objects, lines and areas are usually displayed in maps. In humanities, however, there are many instances where the borders are thin or blended, or objects' attributes are not that explicit. ${ }^{46}$ In this case study, we created a set of maps, beginning with the mapping of spatial objects and only then attaching some non-spatial attributes.

A map helps to navigate in space and to understand the spatial relations. To a reader unaware of the spatial layout of a city, a description of the object's localisation within it - its address - has much lower information value than it does to a local resident. In such a case, it does not make a big difference if a cinema was situated in Poštovská or Gottwaldova street. On the other hand, a local resident would recognise the difference between the two streets straight away; one positioned in the city centre and the other stretching through the neighbourhood with a not so flattering reputation. Moreover, identifying Gottwaldova street on a map might become a challenge even for a local resident familiar with the contemporary layout of the city. The younger generation might not be aware of the fact that after 1989, many of the streets (not only in Brno but in the whole of former Czechoslovakia) changed their names and that the street now called Cejl once used to be known as Gottwaldova street. ${ }^{47}$ Attaching a map to this kind of description gradually increases the understanding of the spatial setting of the city and the positioning of objects within the geographical space, and creates a mental map with relations between the objects based on their mutual distances. With a map at hand, any reader should be able to identify the object of interest and the street it lies in, as well as the estimated distances from reference points, for example the city centre, the train station or other cinemas. In our visualisation, we added one more feature that helps to effectively compare maps of different scales - a set of concentric distance rings. Each 500 metres wide, together they provide the reader with a secondary graphic scale (you can see the primary scale on the bottom of the map) and make the distance estimation easier. We added this feature especially for the comparison of the three cities. To fit the whole cinema network into one map window while simultaneously making it easily readable, we had to use a different scale for each map. The concentric rings, therefore, remind the reader that the maps are of different scales, and the distances need to be assessed separately.

In comparative research, spatial visualisation becomes even more helpful. With a proper map visualisation, we can go beyond comparison of the number of cinemas and their seats and also examine the similarities in their spatial diffusion. Therefore, as a first step, we created a map with all cinema venues. This map can, however, provide more information of a non-spatial nature, for 
example the additional characteristics of the cinemas. In view of the problematic data availability mentioned above, we decided to examine the geographical distribution of venues. We divided them into two groups, represented by colour, according to a simple dichotomy that distinguishes cinemas with and without programmes collected. The reason for this decision is straightforward: we wanted to test if the geographical visualisation can provide us with a better understanding of data availability and help us to assess the usability of the three datasets for the purposes of our case study.

Comparing only the numbers, it might seem that cinemas in Brno lag behind the two Belgian cities in terms of size of cinema network and number of available sources. While in Ghent and Antwerp, we have data for about 30 cinemas, in Brno we have data for only 24 cinemas. We miss programmes of 12 cinemas in Brno, 23 cinemas in Antwerp and only three cinemas in Ghent. The reason for this varies; in the case of Brno, the programmes of some cinemas were not published in the weekly newspaper and therefore were not preserved. In the case of Antwerp, as mentioned before, it has to do with collecting only the programmes of the selected cinemas. To assess the overall state of the data availability in the three cities, we added it to the map visualisation. As we can see on the map of Brno, the cinema network spreads far beyond the 2.5 kilometres designated by the distance rings (Figure 1). More importantly, the venues with missing programmes lie mostly outside of the rings. The reason for such a well-spread cinema network can be found in the history of the urban development of Brno. From 1919 onwards, the formerly autonomous small surrounding municipalities were annexed by the city, forming so-called Greater Brno. ${ }^{48}$ Greater Brno represented primarily an administrative unit rather than a homogenous urban environment, which also means that most of the venues in these former villages and small towns are still perceived as rural or smalltown cinemas rather than part of the urban film culture of Brno. ${ }^{49}$ As these cinemas lie considerably far from the centre of Brno, in neighbourhoods where a rural lifestyle still endures, we can assume a different type of audience here than that in the city of Brno and its closest districts, which are all located within the ring 2.5 kilometres wide.

The map of Antwerp reveals a different situation (Figure 2). Even though the number of cinemas with collected programmes is similar to that of Ghent (Figure 3), it only includes cinemas of the very centre, omitting the western and southern part of the city. Ultimately, we decided to exclude Antwerp from the analysis, as the further steps of analysis and visualisation require more consistent datasets. 


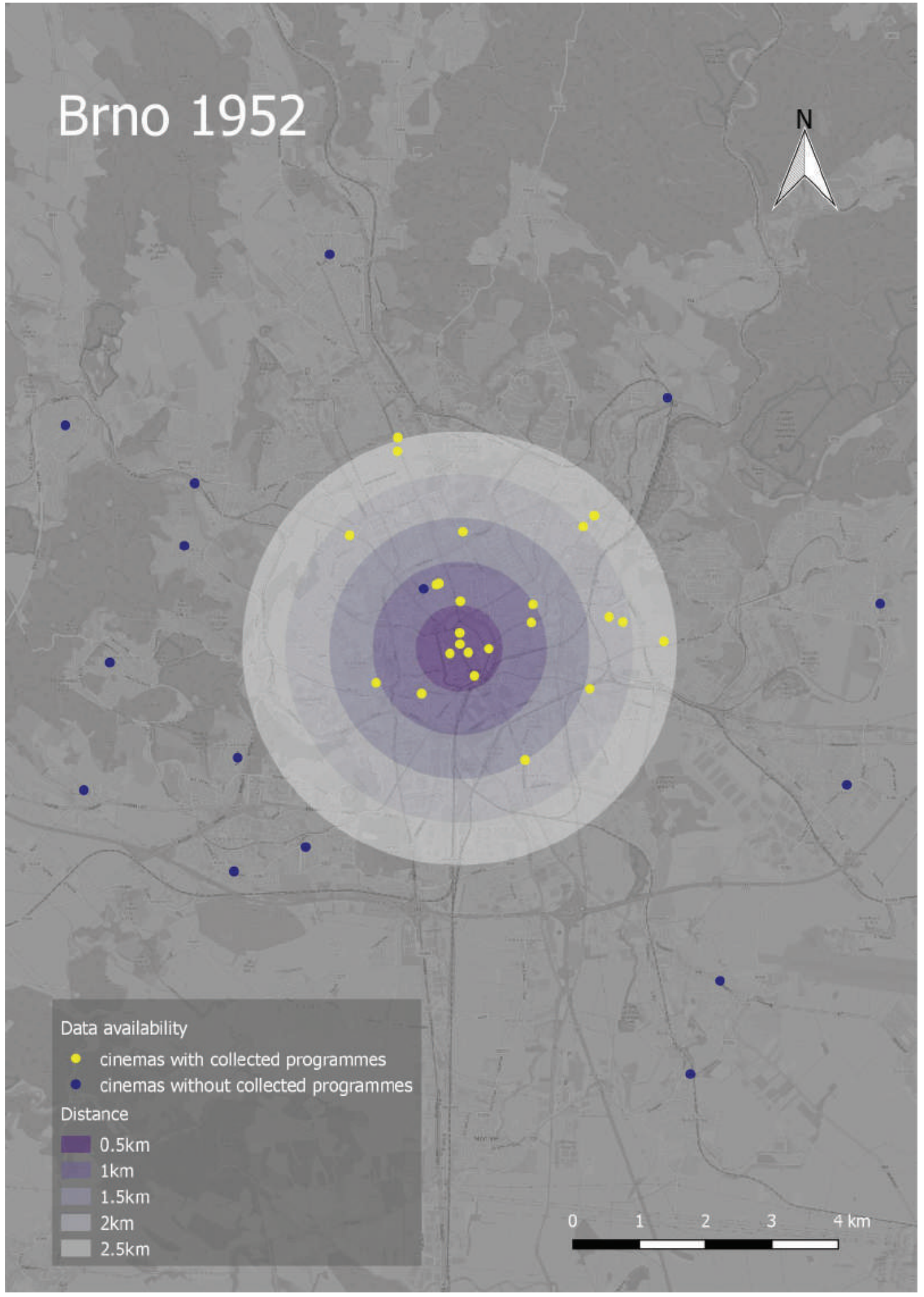

Figure 1. Spatial structure of the cinema network in Brno in 1952 with information on the availability of the cinema programmes. 


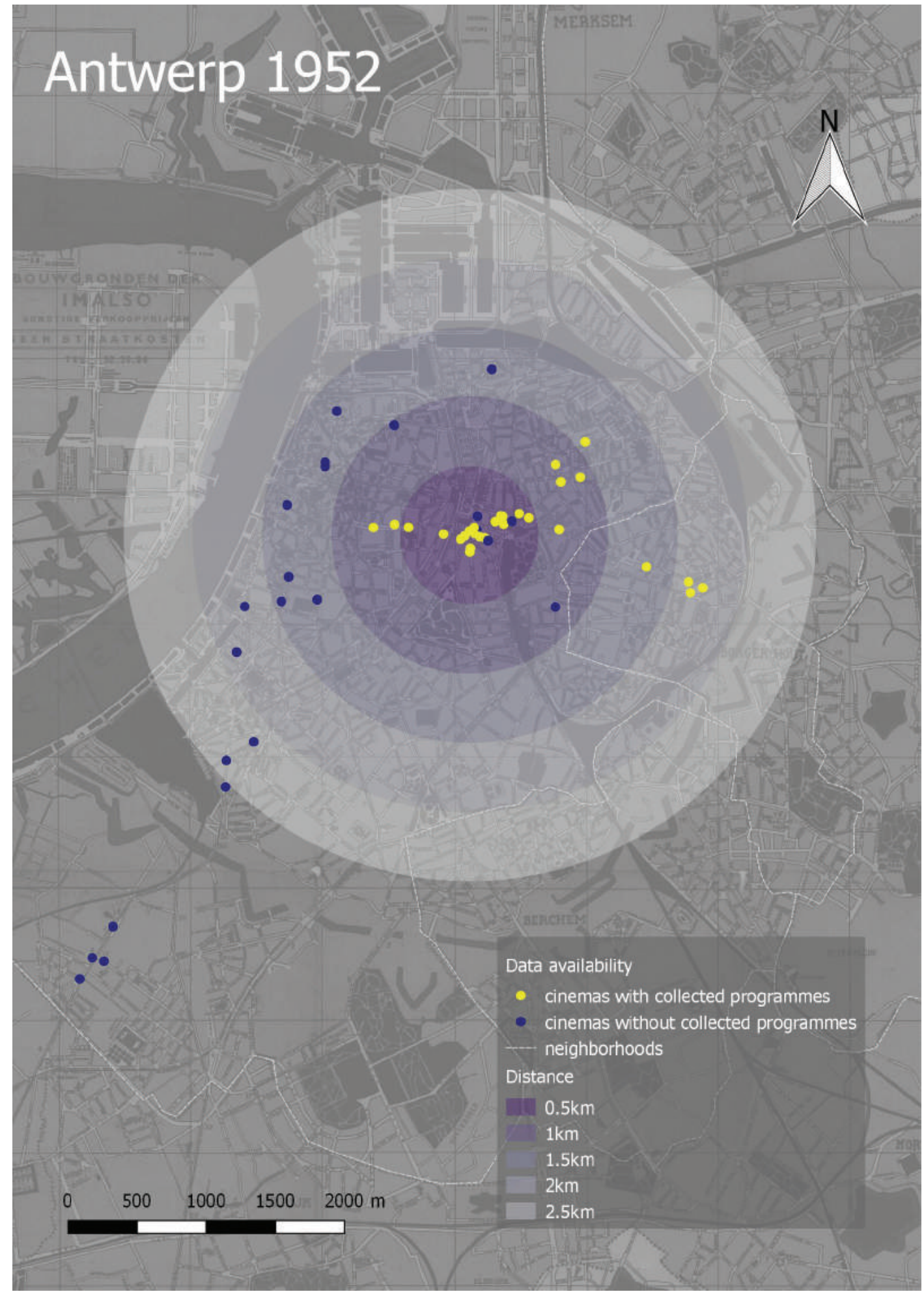

Figure 2. Spatial structure of the cinema network in Antwerp in 1952 with information on the availability of the cinema programmes. 


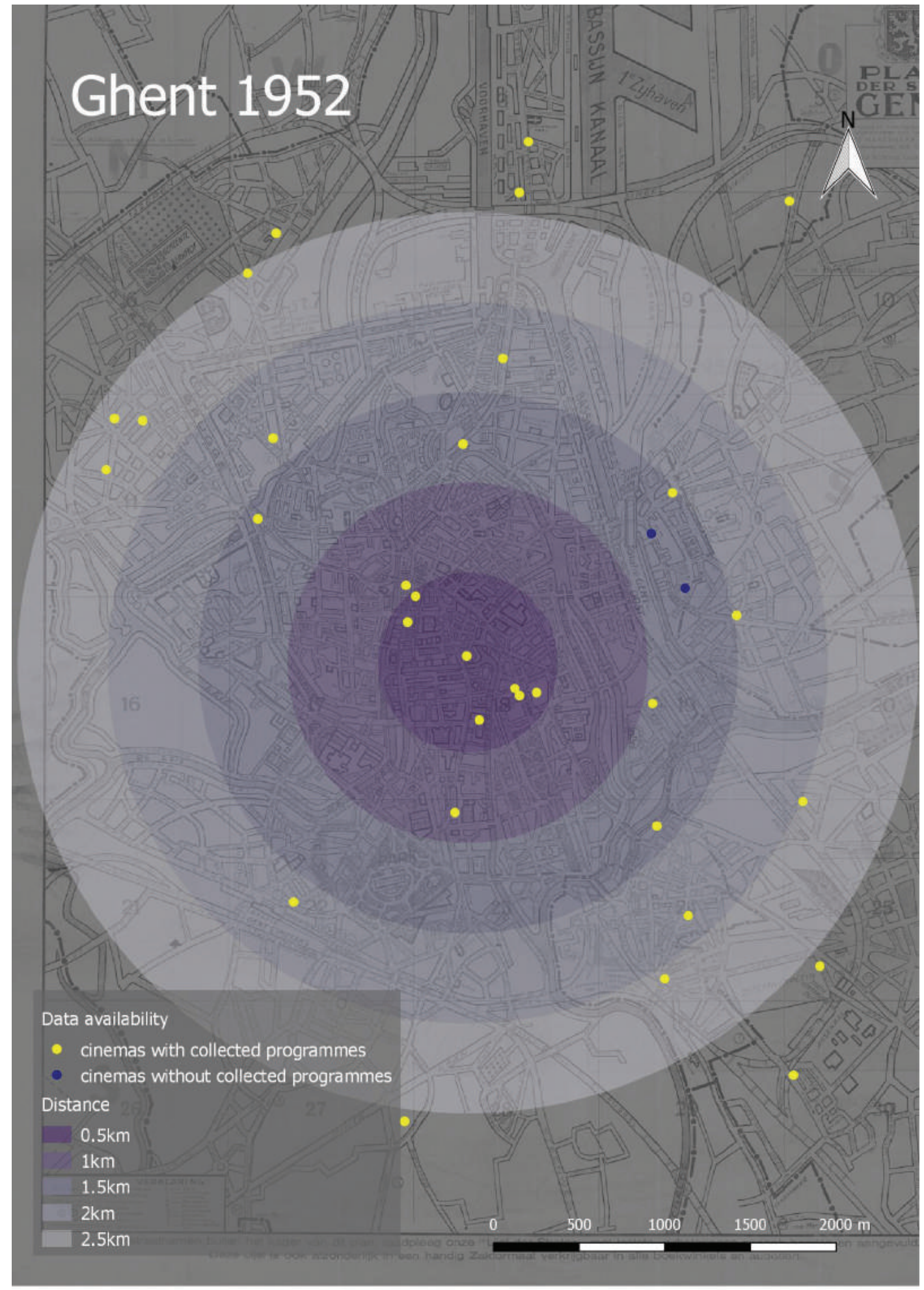

Figure 3. Spatial structure of the cinema network in Ghent in 1952 with information on the availability of the cinema programmes. 


\section{Hierarchy of cinemas}

The ultimate disadvantage of map visualisation is the limited number of attributes of one object that can be displayed simultaneously on a single map. We can work with the size, colour and pattern (in case of lines and areas) of the objects. ${ }^{50}$ To examine the possibilities of spatial analysis, we sought a feature upon which we could categorise cinemas and explore and compare the clusters of categories created on the maps.

Based on the analysis of the film trajectories conducted in this part, we subsequently explored the patterns of cinemas' hierarchies in both cities. The classification of cinemas of firstrun, second-run, etc. - as we know it from the studio system of classical Hollywood in the 1920s-1940s - had its variation in Belgium and Czechoslovakia during World War II. Under the occupation of Nazi Germany, the film industry was centralised and the distribution and exhibition sector fell under German control, which divided cinemas into categories based on factors such as the size of the city they were located in or their seating capacity. ${ }^{51}$ After the end of the war, however, both countries abandoned these models of distribution and, although the film industry in Czechoslovakia was nationalised and centralised under the rule of the communist party in 1948, there was no strict specified hierarchy of cinemas. In Belgium, a similar situation prevailed in the early 1950s. In both countries, therefore, we examine the film trajectories and unveil possible patterns of hierarchisation, developed in practice among the cinemas and possibly prevailing from systems of the former regime.

The quantitative analysis of the cinema programmes here allowed us to estimate the most frequent position of each cinema in the films' trajectories. For each cinema, we analysed the films shown and the phase of their exhibition life in which they were positioned at that moment. The percentage in the tables below (Table 1 and 2) refer to the share of each position (see the columns numbered from 1 up to 18) on the total amount of screened films in given cinema (see the rows). To easily compare the cinemas and to easily identify the maximum and minimum value in each row, we used the 3-colour scale of conditional formatting in Excel. This scale first identifies the median. The cell(s) that hold the maximum value is coloured green, the cell(s) with minimum value is coloured red and the cell with median is coloured yellow. All the other cells are coloured proportionally. This 3-colour scale was applied to each row separately, allowing us to compare the maximum and minimum values of each row and identify the prevailing position in the film trajectories of the 

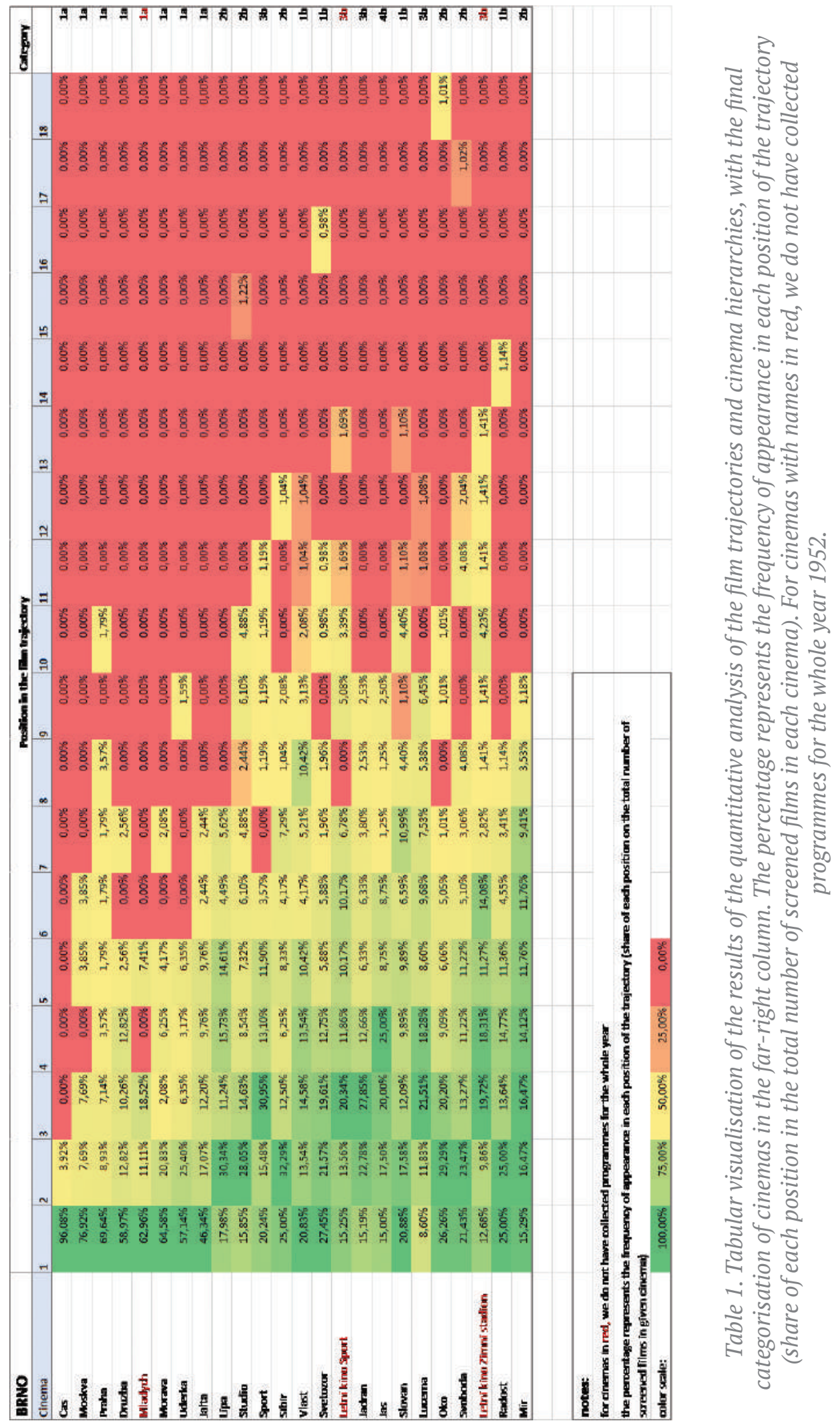


\begin{tabular}{|c|c|c|c|c|c|c|c|c|c|}
\hline \multirow{2}{*}{$\begin{array}{l}\text { GHENT } \\
\text { Cinema } \\
\end{array}$} & \multicolumn{8}{|c|}{ Position in the fin trajediory } & \multirow[t]{2}{*}{ Category } \\
\hline & 1 & 2 & 3 & 4 & 5 & 6 & 7 & 8 & \\
\hline Capitole & $100,00 \%$ & $0,00 \%$ & $0,00 \%$ & $0,00 \%$ & $0,00 \%$ & $0,00 \%$ & $0,00 \%$ & $0,00 \%$ & 1a \\
\hline Century & $100,00 \%$ & $0,00 \%$ & $0,00 \%$ & $0,00 \%$ & $0,00 \%$ & $0,00 \%$ & $0,00 \%$ & $0,00 \%$ & 1a \\
\hline Eldorado & $100,00 \%$ & $0,00 \%$ & $0,00 \%$ & $0,00 \%$ & $0,00 \%$ & $0,00 \%$ & $0,00 \%$ & $0,00 \%$ & 1a \\
\hline Majestic & $97,87 \%$ & $0,00 \%$ & $2,13 \%$ & $0,00 \%$ & $0,00 \%$ & $0,00 \%$ & $0,00 \%$ & $0,00 \%$ & 1a \\
\hline Rex & $94,23 \%$ & $5,77 \%$ & $0,00 \%$ & $0,00 \%$ & $0,00 \%$ & $0,00 \%$ & $0,00 \%$ & $0,00 \%$ & 1a \\
\hline Leapold & $93,75 \%$ & $6,25 \%$ & $0,00 \%$ & $0,00 \%$ & $0,00 \%$ & $0,00 \%$ & $0,00 \%$ & $0,00 \%$ & 1a \\
\hline Sevoy & $93,33 \%$ & $6,67 \%$ & $0,00 \%$ & $0,00 \%$ & $0,00 \%$ & $0,00 \%$ & $0,00 \%$ & $0,00 \%$ & 1a \\
\hline Select & $87,76 \%$ & $12,24 \%$ & $0,00 \%$ & $0,00 \%$ & $0,00 \%$ & $0,00 \%$ & $0,00 \%$ & $0,00 \%$ & $1 \mathbf{a}$ \\
\hline Plaza & $71,74 \%$ & $21,74 \%$ & $4,35 \%$ & $2,17 \%$ & $0,00 \%$ & $0,00 \%$ & $0,00 \%$ & $0,00 \%$ & 1 \\
\hline Rïtz & $70,59 \%$ & $20,59 \%$ & $5,88 \%$ & $2,94 \%$ & $0,00 \%$ & $0,00 \%$ & $0,00 \%$ & $0,00 \%$ & 1a \\
\hline Rahuido: & $70,00 \%$ & $20,00 \%$ & $10,00 \%$ & $0,00 \%$ & $0,00 \%$ & $0,00 \%$ & $0,00 \%$ & $0,00 \%$ & 1a \\
\hline Pax & $62,50 \%$ & $20,00 \%$ & $10,00 \%$ & $2,50 \%$ & $0,00 \%$ & $2,50 \%$ & $0,00 \%$ & $2,50 \%$ & $1 \mathrm{a}$ \\
\hline Vooruit & $55,10 \%$ & $40,82 \%$ & $2,04 \%$ & $0,00 \%$ & $0,00 \%$ & $0,00 \%$ & $2,04 \%$ & $0,00 \%$ & lb \\
\hline Vriernderlkring & $45,45 \%$ & $36,36 \%$ & $9,09 \%$ & $9,09 \%$ & $0,00 \%$ & $0,00 \%$ & $0,00 \%$ & $0,00 \%$ & lb \\
\hline Ganda & $44,68 \%$ & $44,68 \%$ & $8,51 \%$ & $0,00 \%$ & $2,13 \%$ & $0,00 \%$ & $0,00 \%$ & $0,00 \%$ & lb \\
\hline Roxy & $30,77 \%$ & $30,77 \%$ & $17,95 \%$ & $12,82 \%$ & $5,13 \%$ & $2,56 \%$ & $0,00 \%$ & $0,00 \%$ & lb \\
\hline Nowy & $10,20 \%$ & $46,94 \%$ & $30,61 \%$ & $10,20 \%$ & $2,04 \%$ & $0,00 \%$ & $0,00 \%$ & $0,00 \%$ & 2h \\
\hline City & $16,00 \%$ & $44,00 \%$ & $30,00 \%$ & $6,00 \%$ & $4,00 \%$ & $0,00 \%$ & $0,00 \%$ & $0,00 \%$ & Zh \\
\hline Ideal & $38,64 \%$ & $40,91 \%$ & $18,18 \%$ & $2,27 \%$ & $0,00 \%$ & $0,00 \%$ & $0,00 \%$ & $0,00 \%$ & 2h \\
\hline Cameo & $8,00 \%$ & $34,00 \%$ & $22,00 \%$ & $32,00 \%$ & $2,00 \%$ & $2,00 \%$ & $0,00 \%$ & $0,00 \%$ & th \\
\hline Royal & $12,24 \%$ & $28,57 \%$ & $36,73 \%$ & $10,20 \%$ & $8,16 \%$ & $2,04 \%$ & $2,04 \%$ & $0,00 \%$ & 3b \\
\hline Lido & $8,33 \%$ & $14,58 \%$ & $31,25 \%$ & $27,08 \%$ & $14,58 \%$ & $2,08 \%$ & $2,08 \%$ & $0,00 \%$ & 3b \\
\hline Nova & $53,06 \%$ & $20,41 \%$ & $6,12 \%$ & $6,12 \%$ & $10,20 \%$ & $4,08 \%$ & $0,00 \%$ & $0,00 \%$ & 1a \\
\hline Vox & $50,00 \%$ & $19,57 \%$ & $13,04 \%$ & $4,35 \%$ & $2,17 \%$ & $6,52 \%$ & $2,17 \%$ & $2,17 \%$ & Ia \\
\hline Odeon & $46,67 \%$ & $20,00 \%$ & $13,33 \%$ & $4,44 \%$ & $8,89 \%$ & $0,00 \%$ & $6,67 \%$ & $0,00 \%$ & 1 a \\
\hline Rĩo & $14,29 \%$ & $35,71 \%$ & $21,43 \%$ & $23,81 \%$ & $4,76 \%$ & $0,00 \%$ & $0,00 \%$ & $0,00 \%$ & 2h \\
\hline Scaldis & $19,57 \%$ & $21,74 \%$ & $23,91 \%$ & $13,04 \%$ & $8,70 \%$ & $10,87 \%$ & $2,17 \%$ & $0,00 \%$ & 3b \\
\hline Agora & $28,00 \%$ & $28,00 \%$ & $30,00 \%$ & $12,00 \%$ & $2,00 \%$ & $0,00 \%$ & $0,00 \%$ & $0,00 \%$ & 3b \\
\hline Casino & $33,33 \%$ & $16,67 \%$ & $21,43 \%$ & $16,67 \%$ & $9,52 \%$ & $2,38 \%$ & $0,00 \%$ & $0,00 \%$ & 1b \\
\hline Metropole & $10,20 \%$ & $38,78 \%$ & $18,37 \%$ & $12,24 \%$ & $14,29 \%$ & $6,12 \%$ & $0,00 \%$ & $0,00 \%$ & $2 a$ \\
\hline Forum & $14,29 \%$ & $20,41 \%$ & $26,53 \%$ & $16,33 \%$ & $16,33 \%$ & $6,12 \%$ & $0,00 \%$ & $0,00 \%$ & $\mathbf{3 b}$ \\
\hline Nord & $14,00 \%$ & $18,00 \%$ & $22,00 \%$ & $28,00 \%$ & $16,00 \%$ & $2,00 \%$ & $0,00 \%$ & $0,00 \%$ & $\mathbf{A b}$ \\
\hline
\end{tabular}

\section{notes:}

for cinemas in red, we do not have collected programmes for the whole year

the percentage represents the frequency of appearance in each position of the trajectory (share of each position on the total number of sureened films in given cinema)

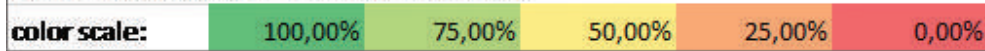

Table 2. Tabular visualisation of the results of the quantitative analysis of the film trajectories and cinema hierarchies, with the final categorisation of cinemas in the far-right column. The percentage represents the frequency of appearance in each position of the trajectory (share of each position in the total number of screened films in each

cinema). For cinemas with names in red, we do not have collected programmes for the whole year 1952. 
cinemas. If a cinema has the highest percentage in column 1, it means that it usually (or always) appeared at the beginning of the film trajectory and therefore category 1 was assigned to them. These venues usually showed films in their local premiere, or were among the first in the city. From the category 1 cinemas, films moved to cinemas of category 2,3 and 4 . This ranking is a simulation of the film circulation around the two cities, based on the programming data rather than a formal institutional decision. The tabular visualisation of the results of this analysis offers some important insights for the comparison of the exhibition practices of the two cities. The general pattern in Brno suggests that the circulation of films around the city was denser, also, the number of cinemas in the longest film trajectory is more than twice as high as in Ghent (Tab 1. and 2.). This might be a result of the considerably lower number of films in circulation in Brno caused by the regulations imposed on the production imported from Western Europe and the USA (see Tab 3.). ${ }^{52}$

For some cinemas, however, it is hard to define the categories. Many of the cinemas oscillate between two or more categories, which refers back to the fact that we are not analysing an official, stable, structure but rather recovering indications of a pattern in film circulation. This ambiguity of categorisation is, however, difficult to transfer onto a map. A map visualisation needs a set of categories well-defined for each object. To include the ambiguity at least partially onto the map, we decided to specify the degree of ambiguity by attaching a letter ' $a$ ' or ' $b$ ' to the category number, where 'a' refers to a cinema with a well-defined category (the difference between the first and second most populated cell in a row is higher than 20\%) and ' $b$ ' to a cinema oscillating between two or more categories (the difference between the first and second most populated cell in a row is lower than 20\%). From the table, it is evident that only cinemas of category 1 reached subcategory 'a'; the rest fall under subcategory 'b’ (Table 1 and 2).

When we compared the spatial dispersion of the categories on the maps of Ghent and Brno, the similarities became more visible (Figure 4 and 5). Even though the cities are positioned in very different social and political settings, it seems that the structure of the exhibition scene does not differ greatly. In the city centres, we find almost all the cinemas of category 1 , basically referring to a premiere type of cinema - usually the most luxurious - with the rest of the categories spread around the city districts. Visualisation and comparison of the cinema networks layout and their categories pose new questions such as: Why are cinemas Rex and Pax, fitting into category 1 , so far from the central part of Ghent? There might be several reasons for that and, in the case of cinema Rex, Daniel 


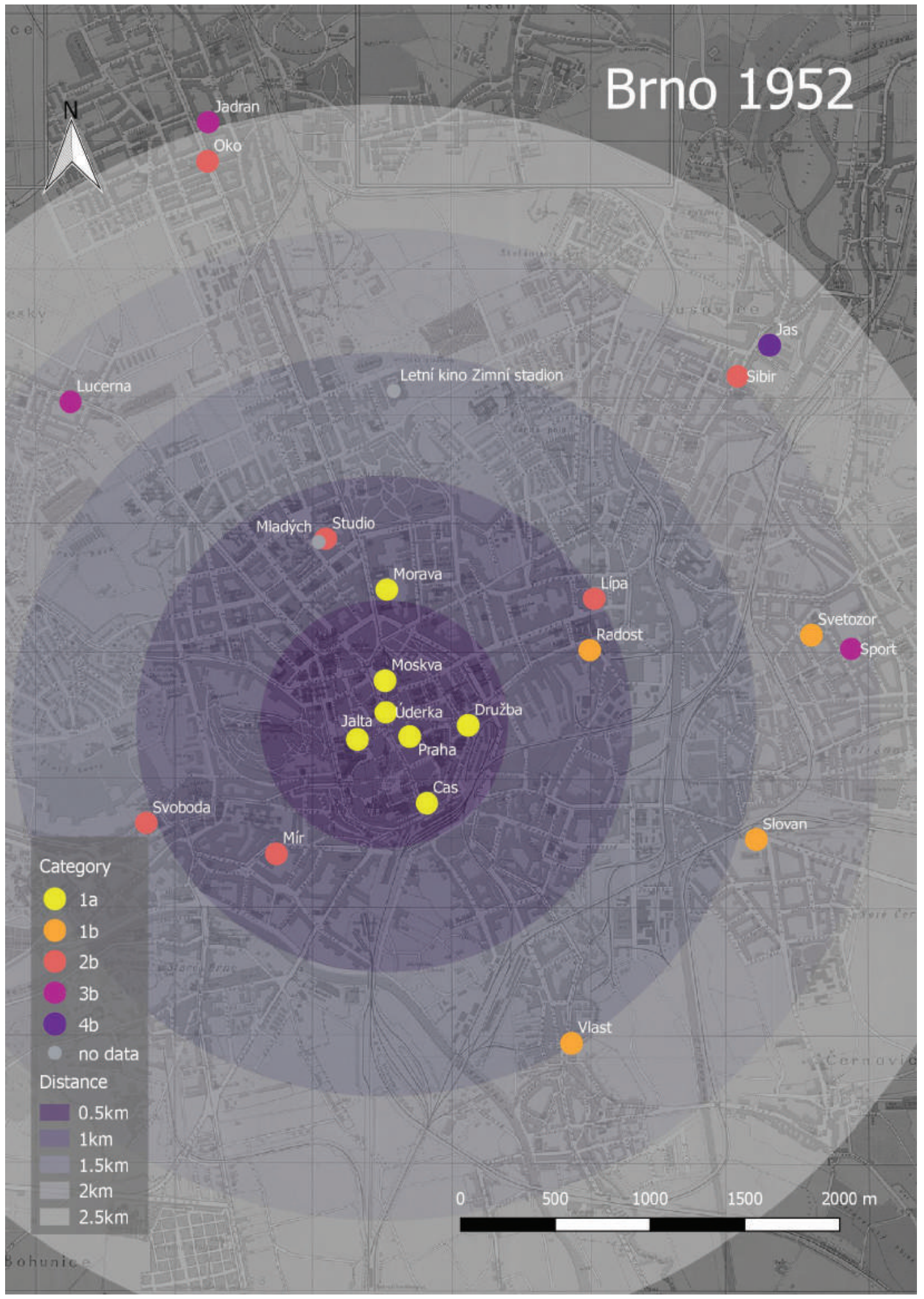

Figure 4. Spatial arrangement of the cinema categories in Brno. 


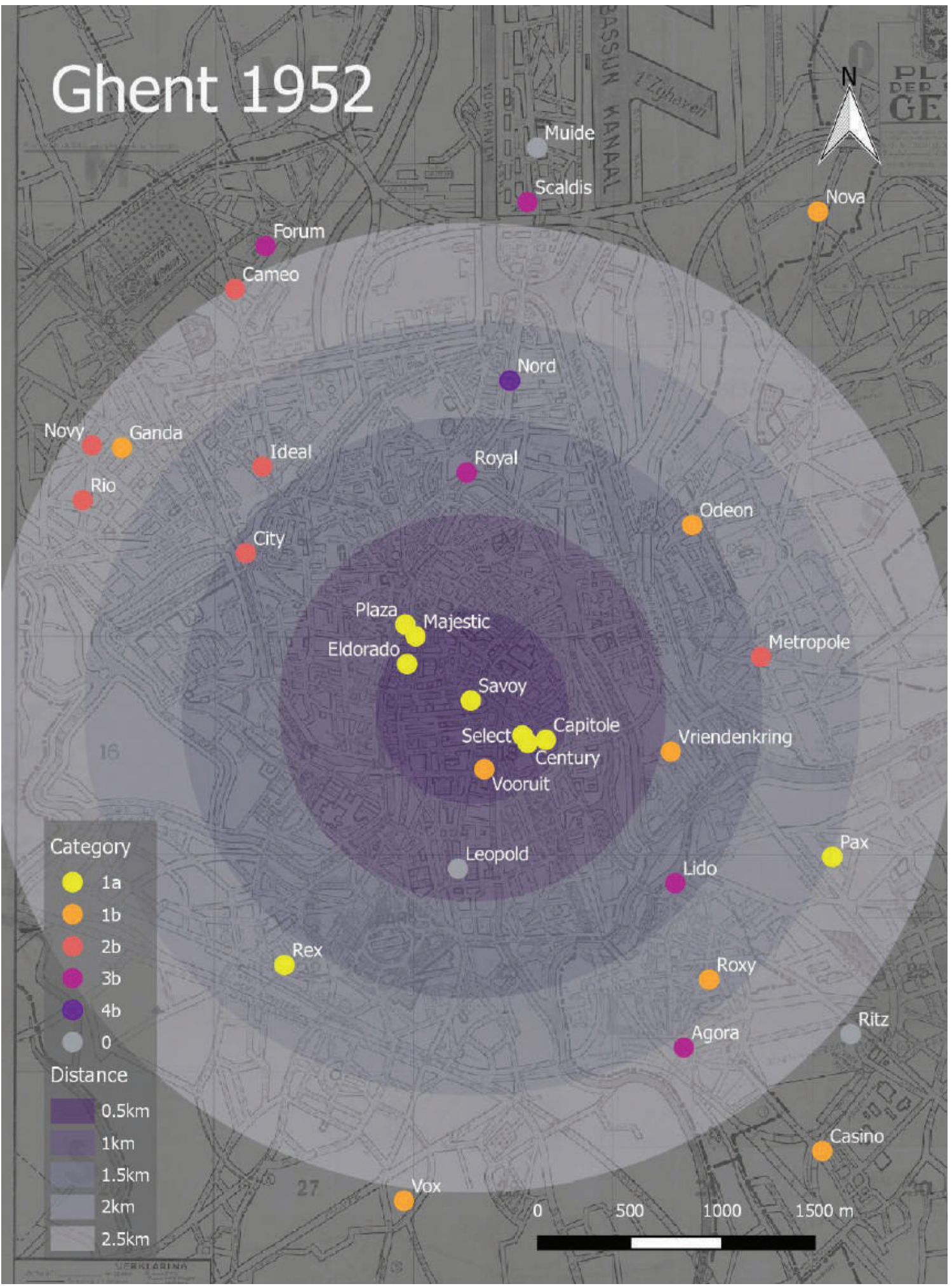

Figure 5. Spatial arrangement of the cinema categories in Ghent. 
Biltereyst, Philippe Meers and Lies van de Vijver explain that in Ghent there was not one but four exhibition centres, one of which was the area around cinema Rex..$^{53}$

The quantitative analysis assigning the categories based on the position of cinemas in the trajectories was performed on the whole dataset, as well as with films that were screened in only one cinema. This might appear both a benefit and a disadvantage. Most of these films, whose circulation did not continue, were niche productions focused on marginal audiences. The quantitative analysis, therefore, puts together the biggest premiere venues and the small venues covering niche productions or fulfilling tastes of a specific type of audience into one category. One way to differentiate between them is to question their position in the city while assuming that picture palaces would not be located in small neighbourhoods but rather in the busy streets and squares. As we saw in the case of cinema Rex in Ghent, this does not always have to be the case. In the case of cinemas Cas and Uderka in Brno, the situation is reversed. These two cinemas are in the very centre of the city, but they are far from being premiere cinemas, which we learned only from additional research. They were both small cinemas showing mostly newsreels and short films in a continuous loop the entire day, with people randomly coming and going at any time. Their location is crucial. Cinema Cas lies in front of the train station, creating a kind of extended waiting room for the travellers. Cinema Uderka, however, was situated in the main square, attracting the attention of bystanders and passers-by with one screen oriented to the street, showing short documentaries and news for free, while having another screen inside with a similar programme but for a fee.

The prevailing pattern forming outside the very central part of both cities are clusters of two or three cinemas of different categories in each district, for example Forum and Cameo in the North and Roxy and Agora in the South of Ghent or Jadran and Oko in the North and Svetozor and Sport in the East of Brno and many others. An exception to this pattern is represented by the trio Rio, Novy and Ganda in the North-West of Ghent, where two cinemas are of the same category. This pattern, one way or the other, raised a question about the film offer of the neighbouring venues. Did the cinema of a higher category forward the films to its neighbour after finishing the screening, and did the cinemas of the same category also share the same films, or was it exactly the opposite, i.e. the film offers differed greatly in order to maintain autonomy over the exhibition scene of a particular neighbourhood? Intrigued by these questions, we propose below another method of how to analyse, visualise and compare cinemas' film offers. 


\section{Network analysis}

To research the similarities in film offers, we used network analysis. Through a detailed display of the relationships between cinemas, we examined the clusters of cinemas with a similar offer of films. We created the network analysis using specialised network visualisation software Gephi. The final network consists of nodes representing the cinemas, and lines (edges) connecting these nodes and representing relationships between them. The colouring of the nodes refers to the cinemas' hierarchy, the colouring of the edges highlighting the strongest relationships while allowing the weak edges to partly blend with the background. The stronger the similarities between cinemas, the thicker and darker the connecting edges and the closer the nodes appear to each other. The distribution of the nodes in the space, therefore, does not represent the geographical space. The distances between nodes inform us about the clusters of nodes - cinemas that were formed based on a selected attribute - in our case allowing us to study the number of same screened films.

The networks of both cities share some similarities. The main pattern reflects, to a certain extent, the reverse constellation of the cinemas in geographical space (Figure 6 and 7). Here, the cinemas of category 1 are mostly spread on the outskirts of the network with only a few links to other nodes. In the centre of the network lie cinemas of lower categories, some of them creating tight clusters. In Brno, the grouping looks more centralised, whereas in Ghent there are several autonomous clusters lying a bit off-centre. This means that the flow of films after their premiere (in cinemas of category 1), especially in Brno, headed to other cinemas without any specific direction, any specific rule or relationship that would direct them to one or two specific cinemas. A similar pattern applies to Ghent, with a few exceptions. The cinemas Plaza, Majestic and Century, three of the category 1 cinemas, lie considerably closer to the centre of the network, and their relations with neighbouring cinemas are relatively strong. This means that the films premiered in these three cinemas would, with a high probability, have moved to one of their closely related neighbours in the network. For example, films from cinema Majestic would have probably gone straight to Royal, Novy or Metropole, with which Majestic had stronger relations than with the rest. Nevertheless, stronger links appear between cinemas of lower categories, creating clusters of two, three or four cinemas. These cinemas might have been in direct mutual communication, inspired by each other in composing the film offer or even managed by the same person or befriended colleagues. 


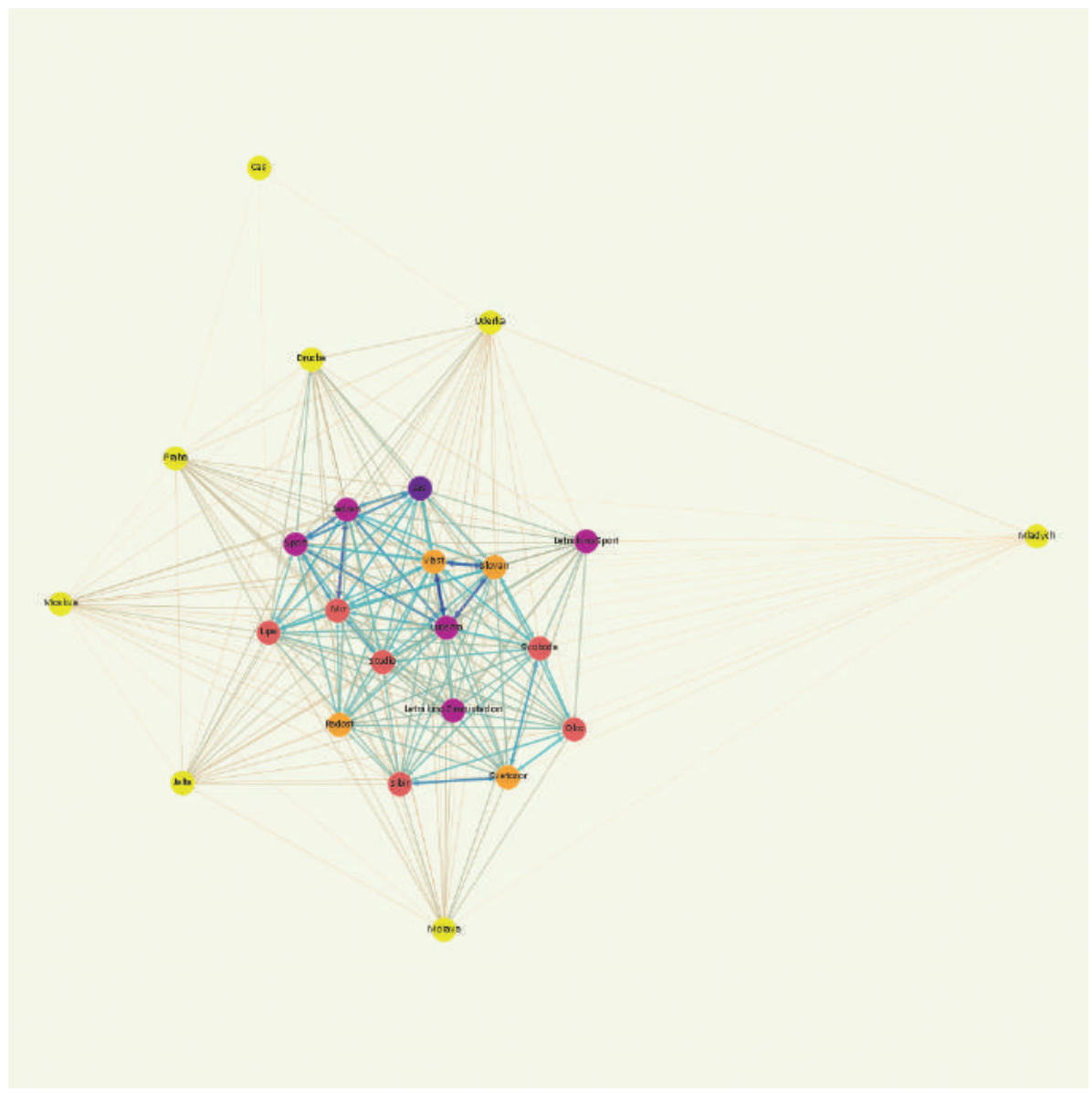

Figure 6. A network of cinemas in Brno showing their mutual relationship based on the similarities of the film offers. The thicker the line connecting two cinemas, the more similarities can be found in their film offers.

The network analysis and additional geospatial visualisation proved to be a helpful tool in answering questions about the relatedness of cinemas while posing new questions about the nature of each relationship. In comparative research, this also enables an efficient method of comparison through a set of visualisations. The graphic display improves the understanding of the network's structure in geographical space, motivating the researcher to analyse the nature of the relationships concerning the spatial structure of the city. It helped us to understand the complementary relationship between the network and geospatial visualisation.

\section{Timelines}

The geospatial visualisation of temporal processes is a popular topic. ${ }^{54}$ In this section, we prioritise the temporal aspect, putting the spatial aside. This is, however, only possible thanks to the three 


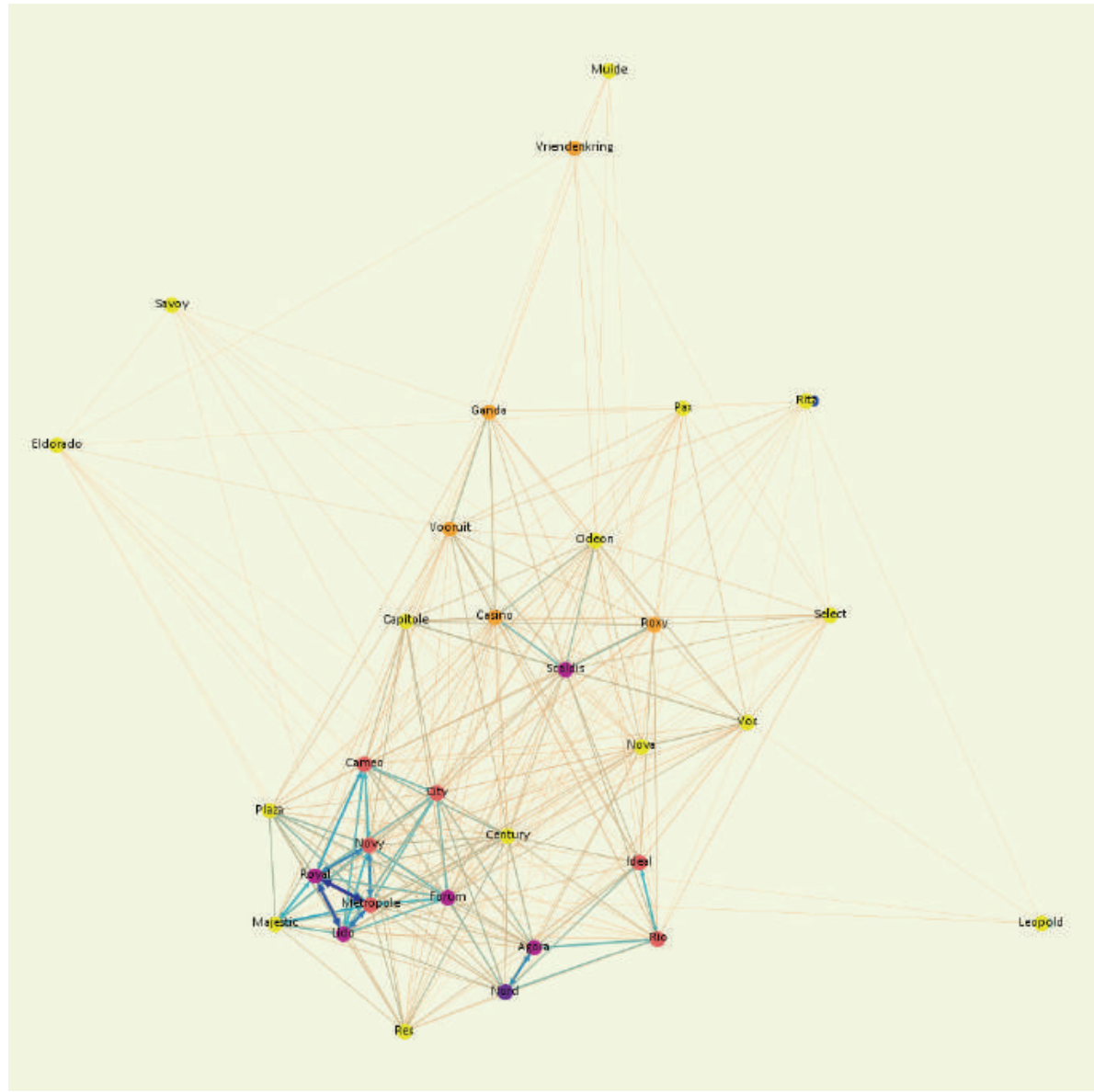

Figure 7. A network of cinemas in Ghent showing their mutual relationship based on the similarities of the film offers. The thicker the line connecting two cinemas, the more the same films were shown in both cinemas.

previous analyses that provided us with a rich and complex geospatial analysis of both cities. ${ }^{55}$ Temporal analysis and visualisation are thus the main objectives of the last part of the case study. We refocus from the spatial to the temporal aspect of the programming data in order to examine the temporal patterns of the local film circulation. The timeframe of this case study is limited to one year, 1952. This might pose a problem in an examination of the temporal patterns of film trajectories, as the exhibition life of a film is usually longer. In this case study, however, we focused more on the method of visualisation and analysis than on the detailed interpretation of the results, proposing a method of static visualisation of the development of given elements in time. A static visualisation of a change in time is challenging but much needed. It is not always possible to present research in a digital, interactive manner that would allow us to freely examine the time axis. Moreover, a 
condensed depiction of a temporal aspect of a process allowed us to contrast the patterns of different cities and make further comparison more efficient.

In the previous analyses, we quantified the film trajectories and analysed the film circulation from a spatial perspective. We identified clusters of cinemas based on the similarities of their film offers. The temporal visualisation and analysis go into even greater detail, considering each trajectory separately. We analysed a selected number of film trajectories, focusing on those that circulated in the highest number of cinemas. This allowed us to examine not only the cinemas in which the film circulated but also the lengths of stays in each of them as well as breaks between the showings. We selected a sample of five films in each city which travelled around the whole city and to the highest number of cinemas. Table 3 shows the distribution of films according to their length of trajectories. In both cities, the most populated is the category in which films exchanged from two to five cinemas and an interestingly high percentage of films was screened only in one cinema. In Brno, the categories with a higher number of cinemas are more populated than in Ghent, which might be related to the considerably lower total number of films on the exhibition scene, 488 in comparison with 650 in Ghent. It is possible that in order to saturate the local demand in Brno, the films had to circulate longer and go through more venues. The last category (films screened in more than 10 cinemas) shows exceptionally long screened films; in Ghent, the longest trajectory encompasses 12 cinemas, in Brno this is as high as 18 cinemas.

\begin{tabular}{|c|c|c|}
\hline Number of cinemas & Brno & Ghent \\
\hline 1 cinema & $32.17 \%$ & $43.08 \%$ \\
\hline $2-5$ cinemas & $47.54 \%$ & $46.00 \%$ \\
\hline $6-10$ cinemas & $16.39 \%$ & $9.85 \%$ \\
\hline$>10$ cinemas & $3.89 \%$ & $1.08 \%$ \\
\hline Total number of film & 488 & 650 \\
\hline
\end{tabular}


For the analysis of the temporal aspect of film trajectories, we selected a sample of films from this category. We created a tabular visualisation displaying the duration of screenings in each cinema in days and the order of cinemas in which the film travelled between them, as well as the the cinema categories which we analysed in the previous paragraph (Tables 4 and 5). On the vertical axis, a calendar is displayed on a daily basis; on the horizontal axis on the top, there are the names of cinemas in the order in which the film moved from one to another. In the middle, the content consists of small coloured blocks, which represent the duration of screenings in the given cinema, while the colour of the block refers to the category of the cinema.

The overall pattern of the film trajectories mostly spreads throughout the year. These films were among the most screened films in the two cities, which gives us reason to believe they were very popular among the audiences. The patterns of the trajectories in the two cities differ significantly. The strategy of circulation in Brno seems more systematic than in Ghent. In Brno, films changed cinemas rather frequently, often after not more than one week. The clearance windows between screenings in two consecutive cinemas was very short or none. After a considerably intense circulation, the film usually completely disappeared from the exhibition scene, with rare occurrences in the later months to be screened for two to four days. In Ghent, on the other hand, the pattern of circulation is more scattered. Unlike Brno, the clearance windows between screenings stretched up to three or four months, after which a seemingly normal and extensive exhibition continued. Furthermore, simultaneous screenings in several venues were far more common than in Brno. During the summer months, all five films disappeared from cinemas almost completely - a practice shared by the cinemas of both cities. Concerning the categories assigned to cinemas in the previous analysis (represented in the timelines by the same colour scheme), it appears that they are not followed very strictly. The resulting patterns here pose more questions for the state of cinema ownership (Can we find instances of shared ownership of several venues?) or the practices in local distribution and exhibition planning (How many film copies were available in local circulation? Did the owners/managers of cinemas collaborate?). Another level could be also added to this analysis, following the comparison with films with shorter trajectories and finding and examining differences in the exhibition pattern. It might be the case that the long-screened films selected for this case study had a certain scheme of distribution exactly because of the higher fluctuation between cinemas. 
TMG $23(1 / 2) 2020$

Terézia Porubčanská, Philippe Meers and Daniel Biltereyst

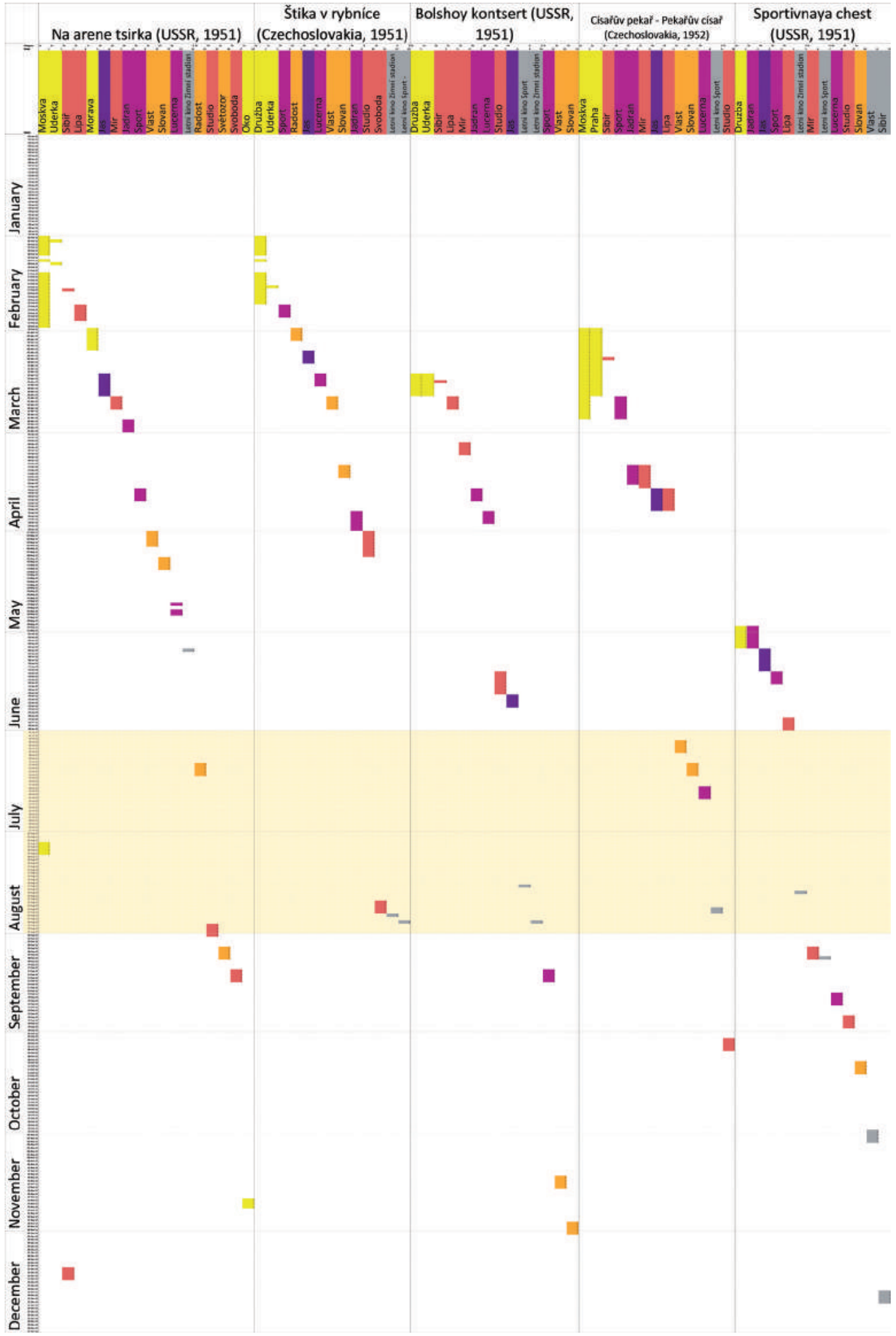

Table 4. Time schedules of five exceptionally long screened films in Brno in 1952.56 
TMG $23(1 / 2) 2020$

Terézia Porubčanská, Philippe Meers and Daniel Biltereyst

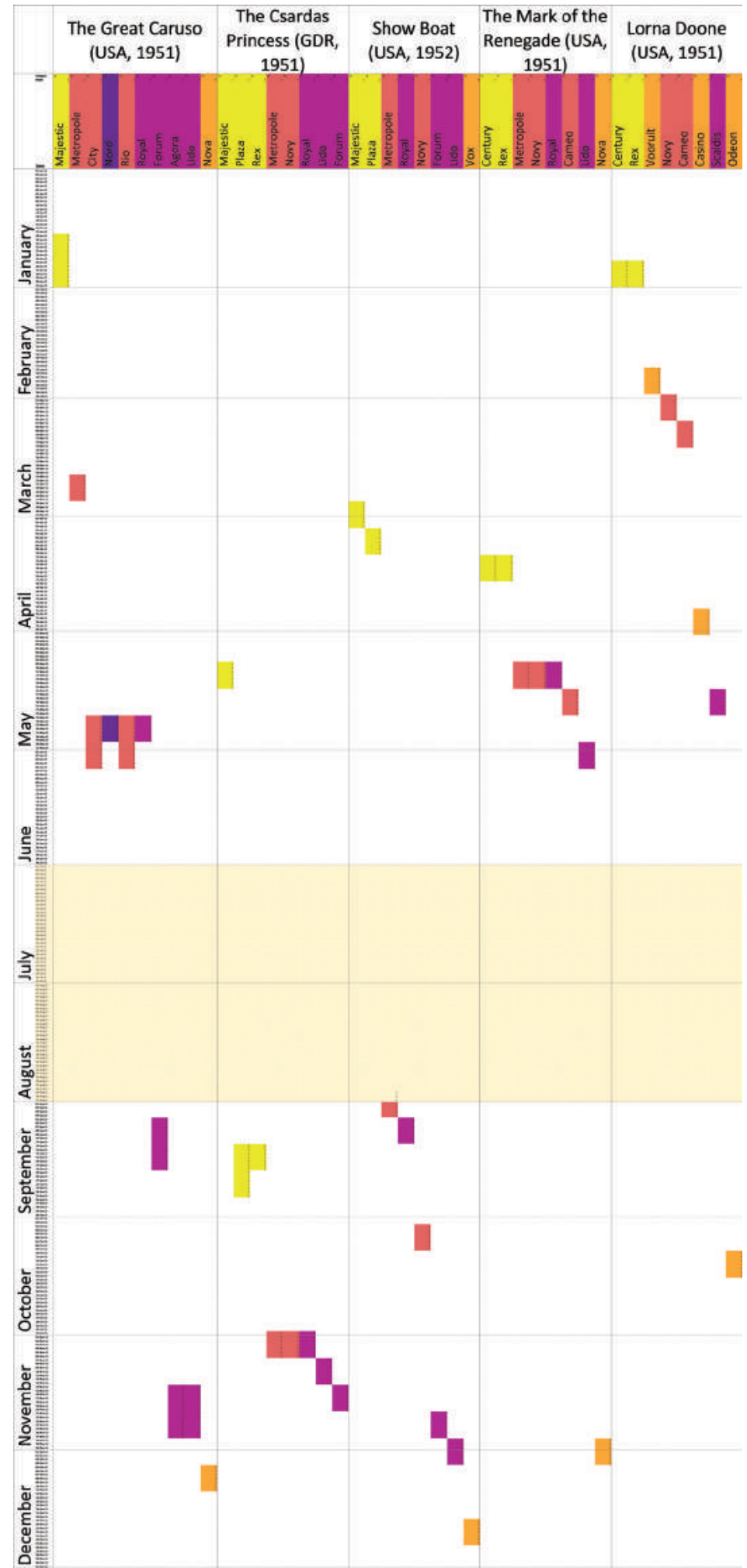

Table 5. Time schedules of five exceptionally long screened films in Ghent in 1952. 
The categorisation is a result of the quantitative analysis of film circulation and the most frequent positions of cinemas within it. It is an analysis of the practices of the cinemas, not an officially imposed categorisation. Furthermore, as we already have discussed, the lower the category was, the more ambiguous the categorisation became. Many cinemas oscillate between two or even more categories. Therefore, it comes as no surprise that the selected films do not strictly follow the categorisation either. This approach, however, might also be very effective in a case study that compares an official hierarchy of cinemas with the actual film trajectories and the extent to which they respect the categorisation.

\section{Conclusion}

The digital tools and methods of spatial and temporal analysis in comparative research introduced in this case study highlight the richness of the data stored in the databases. Without these tools and methods, data collections would just be listings of information. Only with the quantitative analysis and the consequent spatial, network or temporal visualisation were we able to reconstruct a more complex representation of the cinema networks and their exhibition strategies. Standardised results of the quantitative, spatial and network analysis also allowed us to compare the cities despite the differences in their systems of film industries as well as official state ideology.

We used different tools and methods of analysis and visualisation in a study on comparative local cinema histories. In the first part, the main objective concerned the importance of localising cinema venues in their historical urban space. This proved to be an efficient tool of comparison of the different cinema structures in the three cities. In the second part, we applied a quantitative analysis of the programming data to reconstruct a hierarchy of cinemas which emerged from the film trajectories. It has been a challenge to meet the requirements of the mapping tool to have each cinema classified strictly into one category. The map visualisation of the final categorisation lacks the ambiguity required for some cinemas which fall under more than one category. It is, however, the combination of the map and textual or tabular description that makes the overall spatial visualisation complex and meaningful, as mentioned above. The geographical display of the categories also gives us an opportunity to examine their spatial patterns, revealing new relations between the objects. This led us to enquire closer into the relationship between the neighbouring cinemas; specifically, to what 
degree the geographical proximity refers to the proximity in their film offers, asking whether or not the cinemas located close to each other screened the same films. Based on this enquiry, we proceeded to network analysis in the third part of the case study. We analysed the relationships between cinemas from the perspective of the similarities in the film offer. The final network visualisation represents a structure of connections informing us about the similarities in their programming structures. To answer the initial question, we transferred the set of clusters with the strongest relationships back onto the map, only to discover that the neighbouring cinemas share more films with cinemas in the opposite part of the city than between each other. From the comparative perspective, both cities share plenty of similarities, both in the results of the network analysis and the composition of categories. In the last part of this case study, we moved from the search for possibilities for spatial visualisation to proposing a method for visualising a process in time. We analysed trajectories of a selected group of films in each city and displayed the temporal pattern in a set of graphs.

The digital tools represent a powerful aid for data collection, storing, analysis and presentation. They broaden the thinking about historical sources that are usually presented in a textual form. Furthermore, they open avenues to exploring the spatial and temporal patterns as well as the relationships present in these data. The methods examined in this study can be applied to almost any historical context or event, widely exceeding the borders of the field of New Cinema History. In a comparative approach, these methods also offer the means to bring the comparison to the spatial and temporal level. The use of digital tools in comparative research facilitates a comparison on the quantitative level, making it more efficient and more thorough, but, most importantly, it supports interdisciplinary and international collaborations, securing the necessary skills and expertise of a group of scholars. This is a solution to the multidisciplinary nature of research projects but also a method of creating and strengthening the network of academics with a similar focus and raising awareness of similar projects in different parts of the world. The future of these methods in New Cinema History resides in the detailed research of local cinema history and film culture as well as in the various methods for comparing different local cinema histories. This approach requires a division of competences and a group of experts, each focusing on selected local history, as well as their mutual interest in developing a thorough comparison to transform the local, spatial and temporal contexts into a broader historical background. 


\section{Notes}

1. The corpus of works discussing the possibilities of spatialisation in humanities keeps growing every year, but see in particular Doreen Massey, For Space (Sage Publications Ltd, 2005); Anne Kelly Knowles and Amy Hillier, Placing History: How Maps, Spatial Data, and Gis Are Changing Historical Scholarship (Redlands, California: ESRI, Inc., 2008); David J. Bodenhamer, John Corrigan, Trevor M. Harris, The Spatial Humanities: GIS and the Future of Humanities Scholarship (Indiana University Press, 2010); Ian N. Gregory and Alistair Geddes, Toward Spatial Humanities: Historical GIS and Spatial History (Bloomington, Indianapolis: Indiana University Press, 2014); Ian N. Gregory, Don DeBats and Don Lafreniere, The Routledge Companion to Spatial History (Routledge: London, 2018); Robert T. Tally, Topophrenia: Place, Narrative, and the Spatial Imagination (Indiana University Press, 2019).

2 The key publications discussing the pillars of New Cinema History and the potential of quantitative analysis and digital visualisations in cinema studies: Richard Maltby, Melvyn Stokes, and Robert C Allen, eds. Going to the Movies: Hollywood and the Social Experience of Cinema (Exeter, UK: University of Exeter Press, 2007); Richard Maltby, Daniël Biltereyst, and Philippe Meers, eds. Explorations in New Cinema History: Approaches and Case Studies (Malden: Wiley-Blackwell, 2011); Daniel Biltereyst, Richard Maltby, and Philippe Meers, eds., The Routledge Companion to New Cinema History (London/New York: Routledge, 2019).

3 Robert C. Allen and Douglas Gomery, Film History: Theory and Practice (McGraw-Hill Companies Inc., 1985).

4 Richard Maltby, “On the Prospect of Writing Cinema History from Below,” Tijdschrift voor Mediageschiedenis 9, no. 2 (2006); Jeffrey Klenotic, “The Place of Rhetoric in 'New’ Film Historiography: The Discourse of Corrective Revisionism," Film History 6 (1994); Richard Maltby, "New Cinema Histories," in Explorations in New Cinema History, 58-84.

5 As do many of the projects on cinema history, among others also databases such as the Dutch database Cinema Context (http://www.cinemacontext.nl/) or map applications such as Mapping Movies (http:// mappingmovies.unh.edu/maps/erma.html) or Australian Cinemas Map (http://auscinemas.flinders.edu. $\mathrm{au} /$ ), or a combination of them both, as for example in an ongoing project European Cinema Audiences (https://www.europeancinemaaudiences.org/)

6 Most of the big-data mapping projects work with an interdisciplinary and also international team of experts, as for example CAARP (http://caarp.edu.au/), Mapping Cinematographic Territories (https:// 
atlascineproject.wordpress.com/), European Cinema Audiences (https://www.europeancinemaaudiences. org/), and many others.

7 For an overview of the application of digital tools in cinema history research, as for example databases, mapping software or tools for the computational analysis of oral history, see: Michael Ross, Manfred Grauer, and Bernd Freisleben, Digital Tools in Media Studies: Analysis and Research, an Overview (Bielefeld: Transcript Verlag, 2009); Julia Hallam and Les Roberts, eds., Locating the Moving Image: New Approaches to Film and Place (Bloomington, Indianapolis: Indiana University Press, 2014); Laura Horak, "Using Digital Maps to Investigate Cinema History," in Arclight Guidebook to Media History and the Digital Humanities, ed. Charles R. Acland and Eric Hoyt (n.p.: REFRAME Books, 2016), 65-102. On the digital tools in social sciences, see for example: Robert Ackland, Web Social Science: Concepts, Data and Tools for Social Scientists in the Digital Age (SAGE Publications, 2013); Ross, Grauer, and Freisleben, Digital Tools in Media Studies; Charles C. Ragin, The Comparative Method. Moving Beyond Qualitative and Quantitative Strategies (University of California Press, 1987).

8 One of the widely used tools within the humanities that broadened the range of applications is the Geographic Information Systems (GIS), originally developed for the purposes of digital geography and cartography, but over time also used in the humanities, particularly in history, archeology and literature. For a detailed introduction of the GIS in the humanities, see Bodenhamer, Corrigan, and Harris, The Spatial Humanities.

9 The social sciences use a huge variety of data types to examine different aspects of society throughout history. A general overview on the methods and tools of comparison in social sciences: James Mahoney and Dietrich Rueschemeyer, eds., Comparative Historical Analysis in the Social Sciences (Cambridge University Press, 2003).

10 Karel Dibbets, "Cinema Context and the Genes of Film History." New Review of Film and Television Studies 8, no. 3 (2010): 331-42, https://doi.org/10.1080/17400309.2010.499784. See the project here: http://www. cinemacontext.nl/.

11 https://kinomatics.com/about/what-is-kinomatics/.

12 http://gtts.oasis.unc.edu/.

13 http://mappingmovies.unh.edu/maps/erma.html.

14 See Colin Arrowsmith, Deb Verhoeven, and Alwyn Davidson, "A Method for Detecting Geographical Cinema Circuits Using Markov Chains" in Advances in Cartography and GIScience. Volume 2. Lecture Notes in 
Geoinformation and Cartography, ed. A. Ruas (Berlin: Springer-Verlag, 2011), 163-178, https://doi. org/10.1007/978-3-642-19214-2_11.

15 A choropleth map is a popular visualisation technique using area symbols to represent the values marked by areal boundaries such as administrative boundaries. See Alwyn Davidson, "A Method for the Visual Representation of Historic Multivariate Point Data.” PhD diss., RMIT University, 2011, pp. 24; and Colin Arrowsmith, Deb Verhoeven, and Alwyn Davidson, “Exhibiting the Exhibitors: Spatial Visualization for Heterogeneous Cinema Venue Data.” The Cartographic Journal 51, no. 4 (2014): 301-312.

16 Markov Chains is a statistical tool that 'provides a powerful technique for analysing time series events where an initial condition results in a number of alternative outcomes.' See: Davidson, Arrowsmith, Verhoeven, “A Method for Detecting”; also Deb Verhoeven and Brian Morris. "Mapping the Ill Disciplined? Spatial Analyses and Historical Change in the Post-War Film Industry,” in Locating the Moving Image, ed. Julia Hallam and Les Roberts (Bloomington, Indiana: Indiana University Press, 2014), 106-29.

17 The Circos software serves for circular visualisation, enabling the exploration of relationships between objects or positions, and was originally designed for visualising genomic data. See: http://circos.ca/ .

18 See Alwyn Davidson, Colin Arrowsmith, and Deb Verhoeven, "A Method for the Visual Representation of Historic Multivariate Point Data," in Advances in Cartography and GIScience, ed. A. Ruas (2011), 163-178, https://doi.org/10.1007/978-3-642-19214-2; and Alwyn Davidson, Deb Verhoeven, and Colin Arrowsmith. "Petal Diagrams: A New Technique for Mapping Historical Change in the Film Industry," International Journal of Humanities and Arts Computing 9 (10/01 2015): 142-63. For an overview of all the aforementioned methods of visualisation, see also Deb Verhoeven "Visualising Data in Digital Cinema Studies: More Than Just Going Through the Motions?” Alphaville. Journal of Film and Screen Media, no. 11 (2016): 92-104.

19 The Graphomap has been developed within the project Cybercartographic Atlas of Canadian Trade with the World; for details of its application on cinema history data, see: Caquard, Sébastien, Daniel Naud, and Wright Benjamin,"Mapping Film Audiences in Multicultural Canada: Examples from the Cybercartographic Atlas of Canadian Cinema," in Locationg the Moving Image, 130-49.

20 Comparative research is a widely applied approach in media and communication studies; see for instance: Frank Esser and Rens Vliegenthart, “Comparative Research Methods,” The International Encyclopedia of Communication Research Methods (2017); Frank Esser and Thomas Hanitzsch, The Handbook of Comparative Communication Research (London/New York: Routledge, 2013). 
21 Daniel Biltereyst and Philippe Meers, "New Cinema History and the Comparative Mode: Reflections on Comparing Historical Cinema Cultures," Alphaville. Journal of Film and Screen Media, no. 11 (2016): 13-32.

22 For example: Pavel Skopal, Filmová Kultura Severního Trojúhelníku: Filmy, Kina a Diváci Českých Zemí, NDR a Polska 1945-1970 (Brno: Host, 2014); Clara Pafort-Overduin, "Distribution and Exhibition in the Netherlands, 1934-1936," in Explorations in New Cinema History, 125-139; Thunnis van Oort, "Industrial Organization of Film Exhibitors in the Low Countries: Comparing the Netherlands and Belgium, 19451960," Historical Journal of Film, Radio and Television 37, no. 3 (2016): 475-498, https://doi.org/10.1080/0143 9685.2016.1157294. Joseph Garncarz, Wechselnde Vorlieben : Über Die Filmpräferenzen Der Europäer 1896-1939 (Frankfurt am Main: Stroemfeld / Nexus, 2015).

24 For a thorough explanation of the POPSTAT formula see John Sedgwick, Popular Filmgoing in 1930s Britain: A Choice of Pleasures (University of Exeter Press, 2000); for its application in a comparative study see John Sedgwick and Michael Pokorny, "The Film Business in the United States and Britain During the 1930s," The Economic History Review 58, no. 1 (2005): 79-112; or Clara Pafort-Overduin, John Sedgwick, and Lies Van de Vijver, "Identifying Cinema Cultures and Audience Preferences: A Comparative Analysis of Audience Choice and Popularity in Three Medium-Sized Northern European Cities in the Mid-1930s," Tijdschrift voor Mediageschiedenis 21, no. 1 (2018): 102-118, http://doi.org/10.18146/2213-7653.2018.340.

25 Elisa Ravazzoli, “The Geography of Film Production in Italy. A Spatial Analysis Using GIS," in Locating the Moving Image, 150-172.

Colin Arrowsmith, Bronwyn Coate, Stuart Palmer, and Deb Verhoeven, “Using Big Cultural Data to Understand Diversity and Reciprocity in the Global Flow of Contemporary Cinema", in Proceedings of the International Symposium on the Measurement of Digital Cultural Products (Montreal: UNESCO Institute for Statistics), $141-151$.

27 Jerry Brotton, A History of the World in Twelve Maps (Penguin Books, 2012), 16.

28 Thomas Schatz, The American Cinema in the 1940s (New York: Simon \& Schuster Macmillan, 1998).

29 Jiří Knapík, “Czechoslovak Culture and Cinema, 1945-1960,” in Cinema in Service of the State: Perspectives on Film Culture in the GDR and Czechoslovakia, 1945-1960, ed. Lars Karl and Pavel Skopal (Berghahn Books, 2015), 39-68.

30 Kyrill Kunakhovich and Pavel Skopal, "Cinema Cultures of Integration: Film Distribution and Exhibition in the GDR and Czechoslovakia from the Perspective of Two Local Cases, 1945-1960," in Cinema in Service of the State, 275-314. 
31 For more details on the cinema hierarchy in Protectorate, see Jan Havran, "Brněnská kina a jejich hrací řády. Řízení filmové distribuce ve 30. a 40. Letech,” in Filmové Brno. Dějiny lokální filmové kultury ed. Pavel Skopal, Lucie Česálková (Praha: Národní filmový archiv, 2016), 183-199.

32 Douglas Gomery, The Hollywood Studio System: A History (British Film Institute, 2005), 74. and Thomas Schatz, Boom and Bust: American Cinema in the 1940s (New York: Charles Scribner's Sons, 1997), 343.

33 Kathleen Lotze and Philippe Meers, “'They Don’t Need Me in Heaven...There Are No Cinemas There, Ye Know': Cinema Culture in Antwerp (Belgium) and the Empire of Georges Heylen, 1945-75," in Watching Films: New Perspectives on Movie-Going, Exhibition and Reception, ed. Karina Aveyard and Albert Moran (Bristol and Chicago: intellect, 2013), 223-244; Daniel Biltereyst, Philippe Meers, Kathleen Lotze and Liesbeth Van de Vijver, “Negotiating Cinema’s Modernity: Strategies of Control and Audience Experiences of Cinema in Belgium, 1930s-1960s," in Cinema, Audiences and Modernity: New Perspectives on European Cinema History (London/New York: Routledge, 2012), 186-201.

34 Van Oort, “Industrial Organization.”

35 'The Enlightened City': Screen culture between ideology, economics and experience. A study of the social role of film exhibition and film consumption in Flanders (1895-2004) in interaction with modernity and urbanisation (project funded by the FWO/SRC-Flanders, promoters: Philippe Meers, Daniel Biltereyst and Marnix Beyen; Antwerpen Kinemastad. A media historic research on the post-war development of film exhibition and reception in Antwerp (1945-1995) with a special focus on the Rex cinema group - Antwerp University Research Council BOF, 2009-2013, promoter: Philippe Meers; The data are currently not available for the public. Thanks to an ongoing project funded by the FWO (Hercules-project Cinecos, 2018-21), the data from these and other research projects on the history of Belgian historical cinema cultures will be available on a digital data platform in 2021, Cinema Belgica (www.cinemabelgica.be).

36 Gent Kinemastad. A multimethodological research project on the history of film exhibition, programming and cinema-going in Ghent and its suburbs (1896-2010) as a case within a comparative New Cinema History perspective - Ghent U Research Council BOF, 2009-2012, promoter: Daniel Biltereyst; European Cinema Audiences is a comparative research project that explores film cultures in seven mid-sized European cities in the 1950s. The project is funded by the British Arts \& Humanities Research Council (2018-2021) and is led by Oxford Brookes University, Ghent University and De Montfort University, https:// www.europeancinemaaudiences.org/. 
37 Cinematic Brno project focuses on the documentation of the movie exhibition history and cinema-goers' preferences in Brno, in the period 1918-1945. During the period 2008-2011, the project was funded by the Czech Science Foundation (GAČR), https://www.phil.muni.cz/filmovebrno/?id=0\&lang=1.

38 https://www.imdb.com/.

39 The tools and methods presented in this case study were subject of a conference paper: Terézia Porubčanská ,Philippe Meers, and Daniel Biltereyst, “Moving Pictures in Motion. Applying Geographical Visualization in Comparative Research on Local Film Exhibition with a Case Study of Antwerp, Ghent and Brno in 1952," paper presented at the international conference HoMER: Anchoring the New Cinema History, 26 - 28 June 2019, Nassau, the Bahamas.

40 For details on using GIS for the exploration of spatiality of cinema history, see Jeffrey Klenotic, "Putting Cinema History on the Map: Using GIS to Explore the Spatiality of Cinema," in Explorations in New Cinema History, 58-84; For more on ArcGIS software see: https://www.esri.com/arcgis-blog/overview/.

41 For a detailed explanation of the ForceAtlas2 algorithm, see Mathieu Jacomy, Tommaso Venturini, Sebastien Heymann, and Mathieu Bastian, "ForceAtlas2, a Continuous Graph Layout Algorithm for Handy Network Visualization Designed for the Gephi Software” PLoS ONE 9, no. 6 (2014), e98679, doi:10.1371/ journal.pone.0098679.

42 Deb Verhoeven, Kate Bowles, and Colin Arrowsmith, "Mapping the Movies: Reflections on the Use of Geospatial Technologies for Historical Cinema Audience Research,” in Digital Tools in Media Studies, 69-81; See also Steven Johnson, The Ghost Map: The Story of London's Most Terrifying Epidemic - and How It Changed Science, Cities, and the Modern World (New York: Riverhead Books, 2006), an excellent example of how spatial thinking can play an important role in scientific exploration. Brotton, A History of the World in Twelve Maps, 29.

44 Further reading on the limitations of thematic maps and necessity of generalisation in map visualisation: Knowles and Hillier, Placing History, 124-126; Brotton, A History of the World in Twelve Maps, 7-16.

45 More on creating thematic maps: Ian Gregory and Paul S. Ell, Historical Gis: Technologies, Methodologies, and Scholarship (Cambridge University Press, 2007), 89-118.

46 The issue of blending borders between the sociodemographic profiles of Canadian audiences is discussed in their work: Sébastien Caquard, Daniel Naud, and Wright Benjamin, "Mapping Film Audiences in Multicultural Canada: Examples from the Cybercartographic Atlas of Canadian Cinema," in Locationg the Moving Image, 130-149. 
47 The evolution of the names of the streets, squares and other public spaces in Brno is described in Milena Flodrová, Názvy Brněnských Ulic, Náměstí a Jiných Věřejných Prostranství V Proměnách Času (Brno: Šimon Ryšavý, 2009). Karel Kuča, Brno - Vývoj Města, Předměstí a Připojených Vesnic (Praha/Brno: Baset, 2000), 154. On the differences in rural and urban cinemagoing see: Kathryn H. Fuller-Seeley, ed., Hollywood in the Neighborhood: Historical Case Studies of Local Moviegoing (Berkeley: University of California Press, 2008); Kate Bowles, "Beyond the Boundary: Vernacular Mapping and the Sharing of Historical Authority,” in Locating the Moving Image, 221-244; Judith Thissen and Clemens Zimmermann, eds., Cinema Beyond the City: Small-Town and Rural Film Culture in Europe (Palgrave, 2016); Daniela Treveri Gennari, Danielle Hipkins, Catherine O’Rawe, eds., Rural Cinema Exhibition and Audiences in a Global Context (Cham, Switzerland: Palgrave Macmillan, 2018). Gregory and Ell, Historical Gis, 90-94.

51 Jan Havran, “Brněnská Kina a Jejich Hrací Řády. Řízení Filmové Distribuce Ve 30. A 40. Letech,” in Filmové Brno, 183-199; Roel Vande Winkel, “Film Distribution in Occupied Belgium (1940-1944): German Film Politics and Its Implementation by the 'Corporate’ Organisations and the Film Guild,” Tijdschrift voor Mediageschiedenis 20, no. 1 (2017): 46-77, http://doi.org/10.18146/2213-7653.2017.280.

52 For more on the state-regulated system of film industry and the distribution practices in Czechoslovakia during the 1950s, see for instance: Karl and Skopal, Cinema in Service of the State; Pavel Skopal, ed. Naplánovaná Kinematografie: Český Filmový Průmysl 1945 Až 1960. (Praha: Academia, 2012); Filmová Kultura Severního Trojúhelníku: Filmy, Kina a Diváci Českých Zemí, NDR a Polska 19451970; Petr Szczepanik, Továrna Barrandov: Svět Filmařu a Politická Moc, 1945-1970 (Národní filmový archiv, 2016). Daniel Biltereyst, Philippe Meers, and Lies Van de Vijver, "Social Class, Experiences of Distinction and Cinema in Postwar Ghent," in Explorations in New Cinema History, 106-107.

54 Knowles and Hillier, Placing History; Bodenhamer, Corrigan, And Harris The Spatial Humanities; Gregory and Ell, Historical Gis; Edward L. Ayers, "Mapping Time," in GeoHumanities: Art, History, Text at the Edge of Place, ed. Michael Dear, Jim Ketchum, Sarah Luria, and Douglas Richardson (London/New York: Routledge, 2011), $215-225$.

55 See how the issues of mapping the change in time are solved or discussed for example in: Michael F. Goodchild, “Combining Space and Time: New Potential for Temporal Gis,” in Placing History, 179-197; Anne 
Kelly Knowles, Tim Cole, and Alberto Giordano, eds., Geographies of the Holocaust (Indiana University Press, 2014).

In this visualisation, the grey colour refers to the open-air cinemas that operated only during the summer months, therefore they were not included in the analysis of cinema hierarchisation. However, we included them in the timelines in order to keep the complexity of the films' trajectories.

\section{Biographies}

Terézia Porubčanská is a PhD candidate at the University of Antwerp and Masaryk University in Brno, preparing her doctoral thesis on the methods of comparative research in New Cinema History with a case study of Brno, Antwerp and Ghent. She obtained master's degrees in Geography from the University of Pavol Jozef Safarik in Kosice, Slovakia and in Film Studies from the Masaryk University in Brno, Czech Republic. She is involved in a comparative research project European Cinema Audiences researching the cinema culture of Brno, Czech Republic in the 1950s.

Philippe Meers is Professor in Film and Media Studies at the University of Antwerp, Belgium, where he is deputy director of the Visual and Digital Cultures Research Center (ViDi). He has published widely on historical and contemporary film cultures and audiences in, e.g. Screen and Media, Culture \& Society. With Richard Maltby and Daniel Biltereyst, he co-edited Explorations in New Cinema History: Approaches and Case Studies (2011), Audiences, Cinema and Modernity: New Perspectives on European Cinema History (2012) and The Routledge Companion to New Cinema History (2019). With Annette Kuhn and Daniel Biltereyst, he co-edited a special issue of Memory Studies (2017) on memories of cinemagoing.

Daniel Biltereyst is Professor in Film and Media History and director of the Cinema and Media Studies (CIMS) research centre at Ghent University, Belgium. Besides exploring new approaches to historical media and cinema cultures, he is engaged in work on screen culture as a site of censorship, controversy and public debate. He recently published in the Historical Journal of Film, Radio \& Television, Memory Studies and Film Studies. With Richard Maltby and Philippe Meers, he co-edited Explorations in New Cinema History: Approaches and Case Studies (2011), Audiences, Cinema and Modernity: New Perspectives on European Cinema History (2012) and The Routledge Companion to New Cinema History (2019). With Annette Kuhn and Philippe Meers, he co-edited a special issue of Memory Studies (2017) on memories of cinemagoing. He is now finalising Mapping Movie Magazines (Palgrave, with L. Van de Vijver). 


\section{TMG Journal for Media History}

Volume X No 24/2020

DOI

https://dx.doi.org/10.18146/tmg672

\section{PUBLISHER}

Netherlands Institute for Sound and Vision

\section{COPYRIGHT}

Each article is copyrighted (c) by its author(s) and is published under license from the author(s). When a paper is accepted for publication, authors will be requested to agree with the Creative Commons Attribution 4.0 International License. 